\title{
Country Energy
}

\author{
South Africa
}

\author{
August 1995

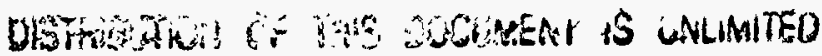




\section{DISCLAIMER}

This report was prepared as an account of work sponsored by an agency of the United States Government. Neither the United States Government nor any agency thereof, nor any of their employees, make any warranty, express or implied, or assumes any legal liability or responsibility for the accuracy, completeness, or usefulness of any information, apparatus, product, or process disclosed, or represents that its use would not infringe privately owned rights. Reference herein to any specific commercial product, process, or service by trade name, trademark, manufacturer, or otherwise does not necessarily constitute or imply its endorsement, recommendation, or favoring by the United States Government or any agency thereof. The views and opinions of authors expressed herein do not necessarily state or reflect those of the United States Government or any agency thereof. 


\section{DISCLAIMER}

Portions of this document may be illegible in electronic image products. Images are produced from the best available original document. 

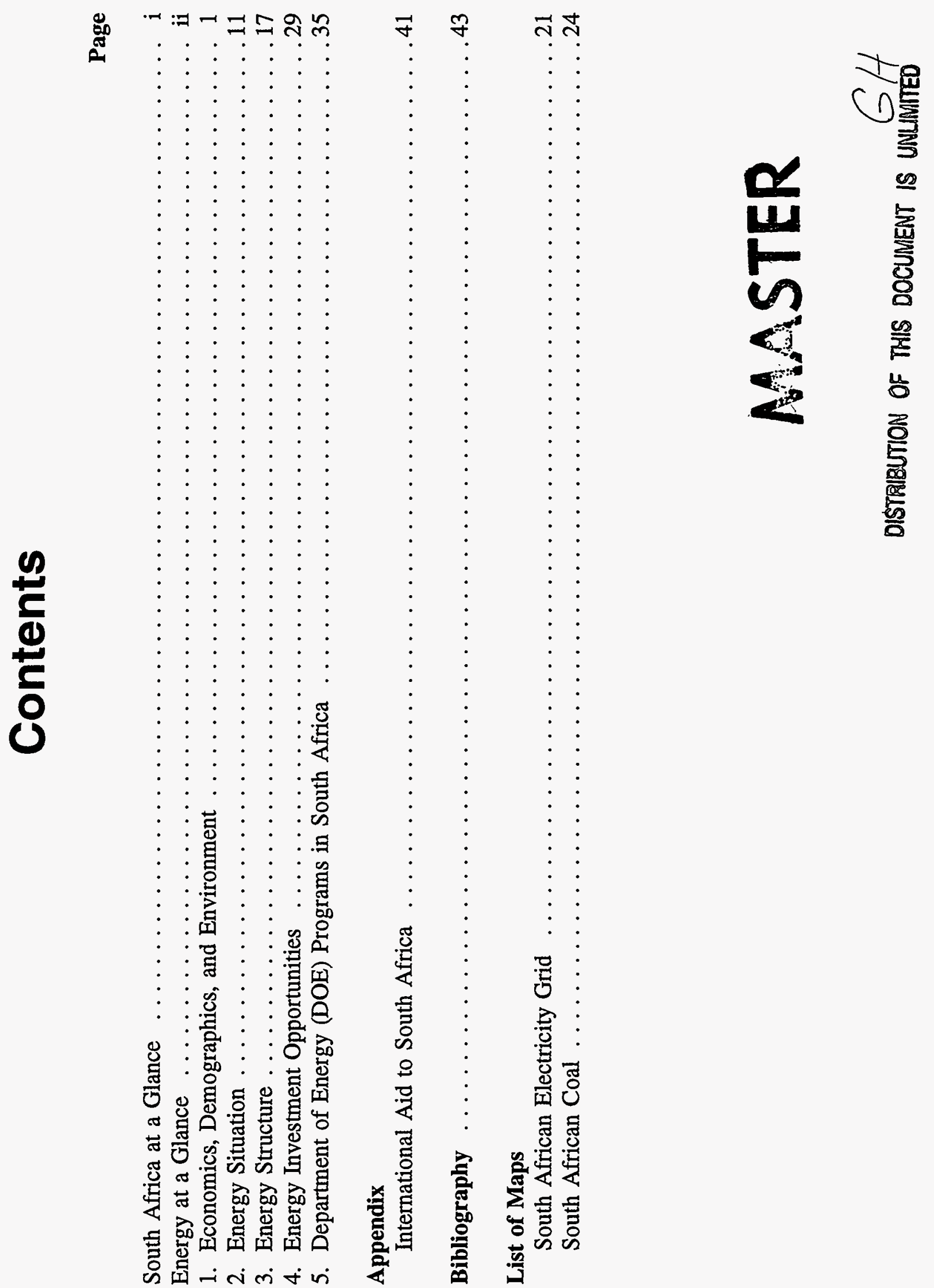

2
2
2
$\frac{5}{3}$
$\frac{3}{4}$

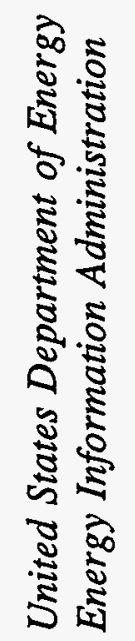




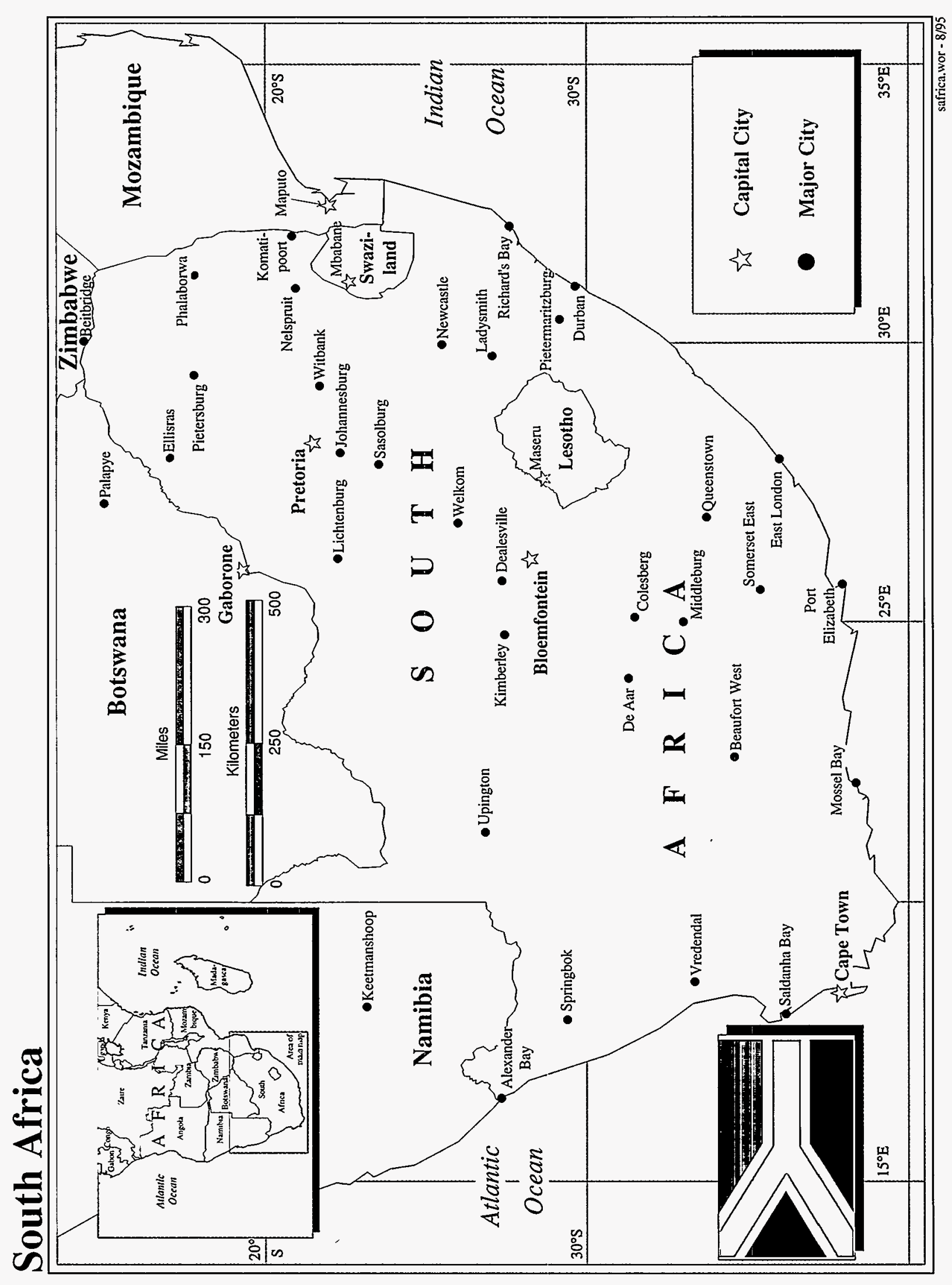

$n$
2
2
5
3
3
3

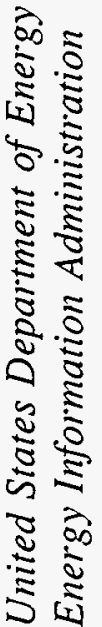


President: Nelson Mandela

First Deputy President: Thabo Mbeki

Second Deputy President: F.W. de Klerk

Government: Federal state, consisting of a central government and nine provincial governments

Major Political Parties: African National Congress (ANC),

National Party (NP), Inkatha Freedom Party (IFP)

Most Recent Presidential Election: April 26-29, 1994

Capitals: Pretoria (administrative), Cape Town (legislative), Bloemfontein (judicial)

Major Economic Centers: Pretoria/Johannesburg/

Witwatersrand area, Durban, Cape Town

Area: 473,290 sq. miles (about twice the size of Texas)

Population (1995E): 42.8 million

Ethnic Groups: Black (75\%), White (14\%), Colored (9\%), Indian (3\%)

Languages: 11 official, including Afrikaans, English, Ndebele, Pedi, Sotho, Swati, Tsonga, Tswana, Venda, Xhosa, Zulu

Religions: Christian (most whites and Coloreds; about $60 \%$ of blacks), Hindu (60\% of Indians), Muslim (2\%)

Climate: Mostly semiarid; subtropical along coast

Currency: Rand

Exchange Rate (7/14/95): US\$1 = 3.65 Rand

Major Products: Gold, platinum, chromium, automobiles

Major Exports (1993): Gold, coal, diamonds, finished goods

Major Imports (1993): Machinery (39\%), chemicals (10\%), finished goods $(7 \%)$

Major Trading Partners: Germany, Japan, United Kingdom, United States

Literacy Rate (1990): Whites (99\%), Asians (69\%), Coloreds (62\%), Blacks (50\%)

Labor Force: Services (35\%), Mining/Industry (30\%), Agriculture (30\%)

\begin{tabular}{|c|c|c|c|}
\hline \multicolumn{4}{|c|}{ Key Economic Indicators } \\
\hline & 1993 & 1994 & 1995 Forecas \\
\hline Population & 40.8 million & 41.8 million & 42.8 million \\
\hline GDP (1987 \$) & 84.6 billion & 86.6 billion & 89.2 billion \\
\hline Real GDP Growth Rate & $1.1 \%$ & $2.3 \%$ & $3.0 \%$ \\
\hline GDP Per Capita (1987 \$) & $\$ 2075$ & $\$ 2073$ & $\$ 2085$ \\
\hline Inflation Rate & $9.8 \%$ & $9.0 \%$ & $10.5 \%$ \\
\hline External Debt & $\$ 16.7$ billion & $\$ 17.8$ billion & $\$ 21.4$ billion \\
\hline \multicolumn{4}{|l|}{ Trade } \\
\hline Exports & $\$ 24.6$ billion & $\$ 24.7$ billion & $\$ 26.2$ billion \\
\hline Imports & $\$ 18.2$ billion & $\$ 20.8$ billion & $\$ 23.2$ billion \\
\hline Overall Trade Balance & $\$ 6.4$ billion & $\$ 3.9$ billion & $\$ 3.0$ billion \\
\hline - with U.S. only & $-\$ 0.4$ billion & $\$ 0.4$ billion & $\$ 0.5$ billion \\
\hline
\end{tabular}

Sources: U.S. Department of Commerce, WEFA Group, and Economist Intelligence Unit

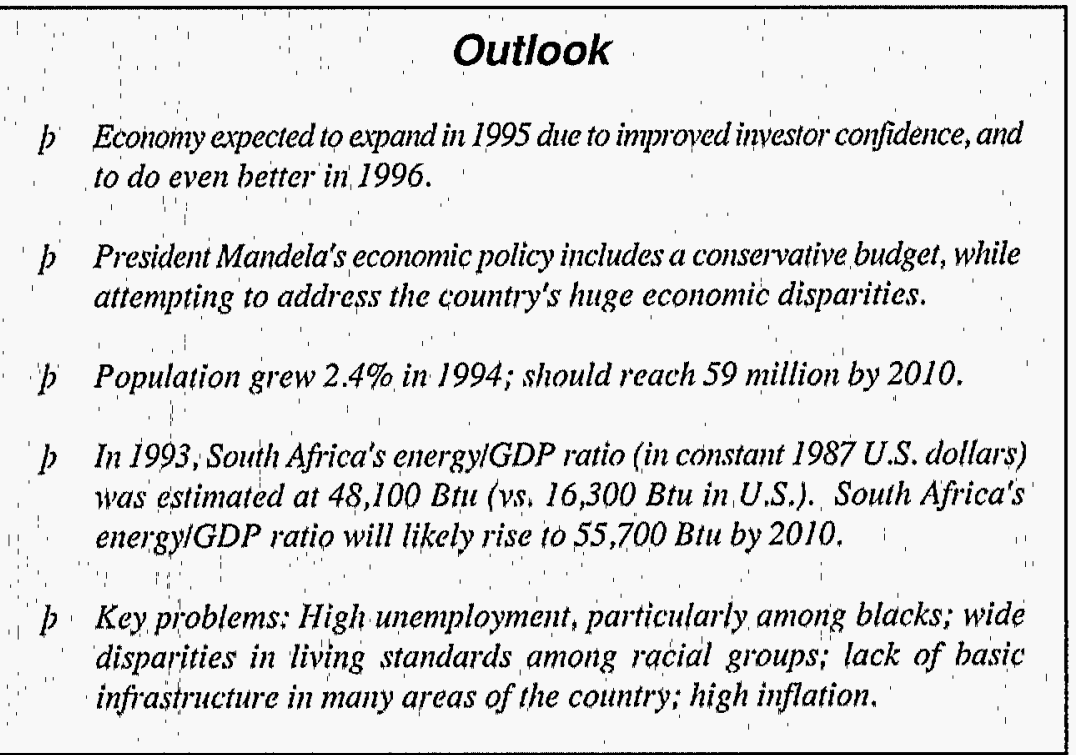

United States Department of Energy

Energy Information Administration

August 1995 


\section{Energy at a Glance}

South Africa's Energy Consumption (1994) $=4.5$ Quadrillion Btu

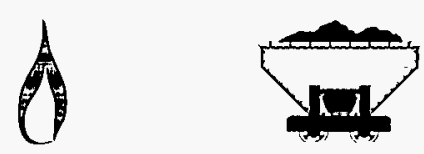

\section{Electric Power in South Africam-An Overview}

1994 Total Net Electricity Generation: 168 billion kilowatthours (95\% Coal-generated, $4 \%$ Nuclear, $<1 \%$ Hydroelectric and other)

- Eskom, the national electric company, generates about $95 \%$ of South Africa's power, and about half of all electricity produced in Africa. Eskom is one of the largest utilities in the world.

- Eskom's 1994 electric generating capacity was estimated at 37.8 gigawatts (GW), from 19 power plants. About $10 \mathrm{GW}$ of Eskom's capacity is considered excess. Industry and mining consume about half of Eskom's electricity generation.

- Electrification in South Africa is highly uneven; many poor rural areas are unelectrified, while richer urban areas are nearly fully electrified. To help narrow this gap, Eskom aims to electrify an additional L.75 million homes_by 2000.

\section{Petroleum in South Africa--An Overview}

1994 Oil Production: 140,000 barrels per day (b/d) incl. synfuels 1994 Oil Consumption: 403,000 b/d

Oil Refining Capacity (1/1/95): 401,000 b/d

- South Africa has nearly no oil reserves, but has a highly developed synthetic fuels industry which produces oil mainly from coal (Sasol), but also from natural gas found in Mossel Bay (Mossgas).

- Oil demand is expected to reach 585,000 b/d by 2010.

- Most international oil companies pulled out for political reasons in the early 1970s. With the end of apartheid, South Africa has attempted to lure foreign oil companies back. To this end, on October 5, 1994, South Africa invited bids for 15 offshore blocks.

\section{Natural Gas in South Africa--An Overview}

1994 Natural Gas Production: 46 billion cubic feet (bcf) Natural Gas Reserves (1/1/95): 959 bcf

- Natural gas makes up less than 1\% of South Africa's fuel supply. Nearly all of this gas is produced in Mossel Bay, and is used to produce synthetic liquid fuel products.

- Although South Africa has nearly no natural gas reserves of its own, regional integration offers the long-term potential for gas imports from either the Pande field in Mozambique or the Kudu field in Namibia.

- Energy Minister Roelf "Pik" Botha announced in November 1994 that the Mossgas synthetic fuels plant was for sale. Possible buyers include Saudi Arabian and Taiwanese refining and petrochemical interests.

\section{Coal-in South Africa-An Overview}

1994 Production: 218 million short tons

1993 Proven Reserves: 61 billion short tons

- Coal accounts for $98 \%$ of South African energy production and $78 \%$ of total consumption. South Africa contains the seventh largest coal reserves in the world.

- South Africa exports large amounts of coal - about 57 million short tons in 1993 - and this amount has increased over the past decade. Along with diamonds and gold, coal is one of South Africa's top three foreign exchange earners.

- Reserves are concentrated in the northeastern Transvaal region, which accounts for around 90\% of national coal production. Reserves are mainly bituminous, with relatively high ash and low sulphur contents. 


\section{Economics, Demographics, and Environment}


South Africa in a World Context: 1993 ...

\begin{tabular}{||l|c|r|r|r|r|r|r|r||}
\hline \multicolumn{1}{|c|}{ Country } & $\begin{array}{c}\text { Gross Domestic } \\
\text { Product } \\
\text { (Billion 1987 } \\
\text { Dollars) }\end{array}$ & $\begin{array}{c}\text { Population } \\
\text { (Millions) }\end{array}$ & $\begin{array}{c}\text { GDP per } \\
\text { Capita } \\
\text { (1987 } \\
\text { Dollars) }\end{array}$ & $\begin{array}{c}\text { Energy } \\
\text { Consumption } \\
\text { (Quadrillion Btu) }\end{array}$ & $\begin{array}{c}\text { Carbon } \\
\text { Emissions* } \\
\text { (Million } \\
\text { Metric Tons) }\end{array}$ & $\begin{array}{c}\text { Energy/GDP } \\
\text { Ratio } \\
\text { (Thousand } \\
\text { Btu/\$1987) }\end{array}$ & $\begin{array}{c}\text { Number } \\
\text { of People } \\
\text { per Car } \\
\text { (1991) }\end{array}$ & $\begin{array}{c}\text { Percent of } \\
\text { Households with } \\
\text { Electricity } \\
\text { (1990) }\end{array}$ \\
\hline Argentina & 125.7 & 33.8 & 3719 & 1.9 & 28.1 & 14.96 & 7.5 & N.A. \\
\hline Brazil & 302.0 & 151.5 & 1993 & 6.2 & 69.3 & 20.40 & 12 & N.A. \\
\hline China & 554.9 & 1205.1 & 460 & 31.7 & 724.3 & 57.07 & 652 & $66 \%$ \\
\hline Former Soviet Union & 481.0 & 285.9 & 1682 & 47.2 & 793.8 & 98.07 & 17 & N.A. \\
\hline India & 345.9 & 896.6 & 386 & 9.1 & 191.7 & 26.34 & 356 & $80 \%$ \\
\hline Indonesia & 111.5 & 189.1 & 590 & 2.6 & 47.8 & 23.41 & 136 & $24 \%$ \\
\hline Mexico & 164.0 & 91.2 & 1798 & 5.1 & 91.4 & 31.38 & 12 & N.A. \\
\hline Poland & 57.4 & 38.5 & 1491 & 4.8 & 114.5 & 83.80 & 6.2 & N.A. \\
\hline South Africa & 84.6 & 40.8 & 2075 & 4.1 & 97.8 & 48.09 & 12 & $36 \%{ }^{* *}$ \\
\hline South Korea & 203.9 & 44.1 & 4624 & 5.0 & 90.3 & 24.28 & 16 & $100 \%$ \\
\hline Turkey & 89.4 & 60.2 & 1485 & 2.4 & 44.5 & 27.18 & 31 & N.A. \\
\hline United States & 5134.5 & 257.6 & 19932 & 83.9 & 1474.3 & 16.34 & 1.7 & $100 \%$ \\
\hline World Total & 18704.0 & 5581.7 & 3351 & 345.3 & 6045.5 & 18.46 & 11 & N.A. \\
\hline
\end{tabular}

'Converted using market exchange rates.

"From commercial fossil fuel consumption only (excludes "traditional" fuels such as wood and biomass).

**atest figure is approximately $40 \%$ of households. 


\section{The People of South Africa ...}

- South Africa is the 25th most populous country in the world; annual growth rate was about $2.4 \%$ in 1994.

- Currently estimated at about 43 million, population should reach 59 million by 2010 .

- Population density varies widely, with an average density of about 90 people per square mile.

- $57 \%$ of the population lives in urban areas.

- Mining and manufacturing are the main bases of the economy, accounting for about $\mathbf{4 0 \%}$ of gross domestic product (GDP) and the vast majority of export earnings.

- Important industries include minerals (platinum, gold, chromium, and coal), automobile assembly, metalworking, machinery, textiles, iron and steel, chemicals, fertilizers, and foodstuffs.

n About $30 \%$ of the labor force is employed in the agricultural sector, which accounts for about $5 \%$ of GDP. South Africa is basically selfsufficient in food.

- About $30 \%$ work in mining/industry, and 35\% in services.

South Africa's Population

Women are reported to comprise $36 \%$ of the labor force, but this excludes the large number of women engaged in agricultural and household work.

- Ethnically, most South Africans (75\%) are black.

- Minority ethnic groups include whites (14\%), Coloreds (9\%), and Indians (3\%)

- Most whites are Christian, as are $60 \%$ of blacks. $60 \%$ of Indians are Hindu.

- South Africa recognizes 11 official languages, including Afrikaans, English, and Zulu. 


\section{South Africa: Important Recent Developments}

1986 Nobel Peace Prize winner Bishop Desmond Tutu calls for Westem nations to implement sanctions on South Africa in order to pressure its govemment to end apartheid. The United States passes the Comprehensive Anti-Apartheid Act, which places stringent economic sanctions on South Africa.

1988 Partly as a result of intemational economic sanctions, South Africa's economy suffers through the first year of a severe recession which will ultimately last through 1993.

1989 On August 14, South African President P.W. Botha resigns, and is replaced by F.W. de Klerk.

1990 South Africa lifts its ban on the previously outlawed African National Congress (ANC), releases ANC leader Nelson Mandela, and repeals the Separate Amenities Act, the legal basis for segregation in public places.

1991 In February, President de Klerk announces plans to end all apartheid laws. In response to this and other moves, most U.S. economic sanctions are lifted by Executive Order 12769 on July 10.

1993 The South Africa Transition to Democracy Act of November 23 leads to removal of nearly all remaining U.S. sanctions. U.S. Commerce Secretary Ronald Brown completes an historic trade and investment mission to the country in December.

1994

April 29 South Africa completes three days of voting for the first democratic, non-racial government in its history. Nelson Mandela is elected President.

May The United States grants South Africa Generalized System of Preferences (GSP) status, allowing approximately 4,300 South African agricultural and semi-finished goods to enter the United States duty free.

May 25 The U.N. Security Council lifts sanctions on ams trade with South Africa.

June 15 U.S. restrictions on sales of goods and senices to the South African military and police are removed.

August 29 South Africa joins the Southem African Development Community (SADC).

September Trans-Natal merges with Randcoal, creating Ingwe Coal Corporation, the world's third largest privately owned coal producer and largest steam coal exporter.

1995

February 21 South Africa's Reserve Bank announces a series of monetary tightening measures, including increased interest rates, as part of its international financial integration strategy.

March 1 U.S. Vice President AI Gore and South African Deputy President Thabo Mbeki set up a bi-national commission (the Gore-Mbeki commission) to improve cooperation and end trade barriers between the two countries.

March 13 The South African govemment merges the commercial and financial rands, abolishing the country's two-tiered currency system. This move should allow foreign investors to withdraw or invest freely, based on market conditions.

March 15 The Mandela govemment's first budget is announced. Main goals include reducing the fiscal deficit, resuming steady growth without inflation, and at the same time eliminating the separation between South Africa's relatively wealthy minority and poorer majority through increased spending on social services. 
- South Africa's economy, after several years of recession, has begun to grow. Serious problems remain, however.

- In 1994, South Africa's real GDP grew about 2.3\%, but its GDP per capita (1987 U.S. dollars) fell slightly to $\$ 2073$ (from $\$ 2075$ in 1993). GDP is forecast to grow about 3\% in 1995 , compared to population growth of $2.4 \%$.

- Unemployment is a key economic problem in South Africa; in 1994, the country's unemployment rate was $32 \%$. The rate was especially severe among blacks (41\%), but was only $6.4 \%$ among whites.

- Consumer prices are expected to increase at a $10.5 \%$ rate in 1995 .

- South Africa's economy contains a well-developed infrastructure, a sophisticated financial sector, and potential for strong growth. Serious disparities in income and living standards remain, however.

- The Mandela government's first budget (announced March 15, 1995), is generally viewed as fiscally conservative, reducing the fiscal deficit and assuming a real growth rate of $2.7 \%$.

- Government priorities include resuming steady economic growth without inflation, while eliminating the separation between South Africa's "first world" minority and "third world" majority largely through the Reconstruction and Development Program (RDP).

- South Africa's industrial sector, including mining and manufacturing, makes up $42 \%$ of the economy.

\section{South Africa's Gross Domestic Product*}

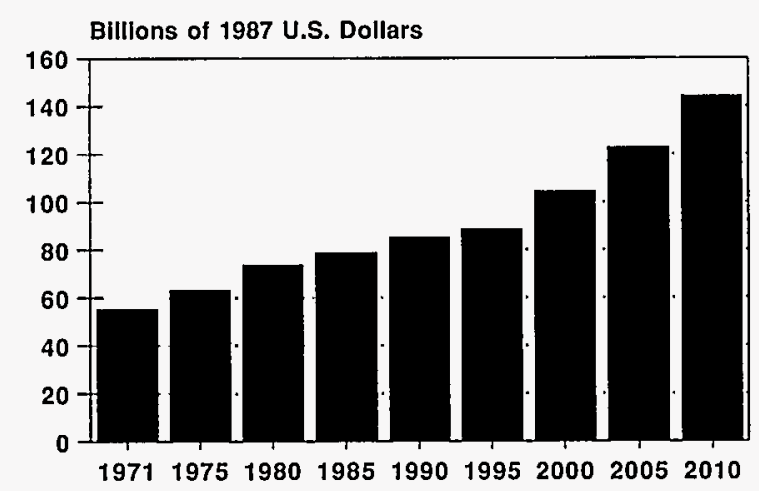

Sourco: Energy Information Adminiatration Exchange Rate Valuation

- Agriculture contributes only 5\% of GDP, although it employs about $30 \%$ of the workforce. The sector includes large numbers of small farms at subsistence levels. A drought during the summer of 1995 reduced total crop production -- especially for corn, the main staple crop.

- On March 13, 1995, the government took an important step towards eliminating remaining exchange controls from the years of apartheid by abolishing the country's two-tiered currency system.

- Since 1979, foreign investment had been transacted using the financial rand. 


\section{South Africa's Reconstruction and Development Program (RDP) ...}

- The RDP is the country's 5-year blueprint for a fundamental transformation of the country. It is estimated to cost $\$ 22.6$ billion.

- According to a White Paper published in September 1994, the RDP seeks no less than the "final eradication of the results of apartheid," including the construction of a "democratic, non-racial, and non-sexist future...for the fundamental transformation of South Africa."

- The RDP contains six basic principles: 1) integration and sustainability; 2) people-driven; 3) peace and security; 4) nation building; 5) meeting basic needs and building infrastructure; and 6) democratization. The RDP emphasizes education and training, housing, health care, electrification, telecommunications, and job creation.

- The RDP calls for closing the gap between the modern, economically prosperous minority of the country and the vast majority of the country living in abject poverty.

- A major goal of the RDP is an "employment-creating, labor-absorbing economy which will ultimately lead to full employment."

- The RDP also aims to provide basic services to millions of households currently lacking them. For instance: as of 1994 only $27 \%$ of black homes had access to running water, $31 \%$ to electricity, and $12 \%$ to telephone service. For whites, the comparable figures were $98 \%, 98 \%$, and $87 \%$, respectively.

- In order to accomplish these goals, the RDP calls for an "enabling role of the state, a thriving private sector, and active involvement by all sectors of civil society."

- "Electricity for all" is the RDP's top energy-related goal.

- The RDP calls for providing electricity for an additional 2.5 million households by 2000 , thereby increasing electric power access to $72 \%$ (vs. about $40 \%$ now). Since Eskom, the state utility, currently maintains significant excess generating capacity, the main challenges to achieving this goal will be extending the electric power grid to areas not currently served.

- To provide this electricity, the RDP calls for employing both grid and non-grid sources, including renewable energy. 


\section{South Africa in the International Market ...}

- South Africa has a long history of policies aimed at protecting domestic industries against foreign competition, and in general maintaining inward-looking development policies. This situation has begun to change over the past several years, and could accelerate with the end of international economic sanctions. In February 1995, President Mandela called for a Marshall Plan-type reconstruction program to "eradicate the mess created by apartheid."

- South Africa's current account (i.e., trade in goods and services) deficit in 1995 is estimated at $\$ 1.2$ billion, or about $1 \%$ of GDP. South Africa relies heavily on its mining sector for the country's export earnings. In 1994, gold alone accounted for $\mathbf{2 9 \%}$ of export revenue, with diamonds, coal, precious metals and agricultural products combining for another $35 \%$.

- South Africa's total foreign debt is expected to reach $\$ 21.4$ billion in 1995 , up from $\$ 17.8$ billion in 1994 .

- The country's debt service ratio has remained steady at about $10 \%$ in recent years.

- In March 1995, South Africa recorded its first merchandise trade deficit in more than a decade, although it rebounded somewhat in April.

\section{South Africa's Trade Balance* 1994-1995}

- May 1995 exports of goods totaled 8.9 billion rand, up

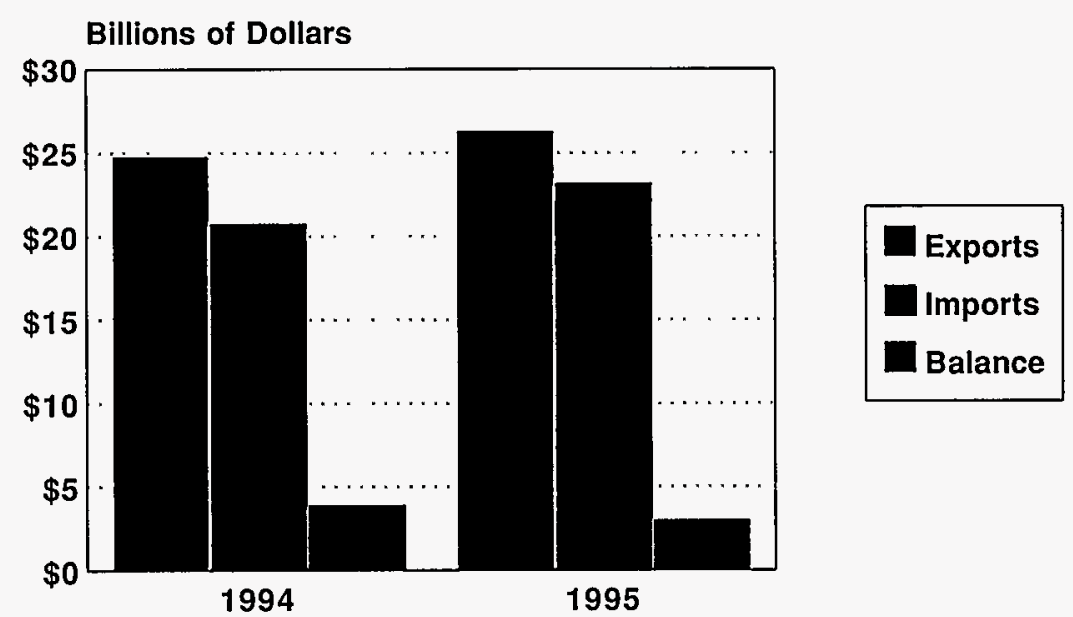

$33 \%$ from a year earlier. At the same time, imports rose $49 \%$ (to 9.1 billion rand) vs. May 1994.

- South Africa's chief trading partners are the United States and Western Europe. 


\section{U.S.-South Africa Business and Trade ...}

- The United States is South Africa's second largest trading partner, after Germany. In 1994, the United States exported $\$ 2.3$ billion, and imported $\$ 1.9$ billion in merchandise from South Africa.

* South Africa's relative importance as a U.S. trading partner has remained about constant in recent years.

- Leading U.S. export prospects include aircraft and parts, industrial chemicals, computers, pharmaceuticals, telecommunications equipment, and building and housing products. U.S. imports are dominated by gold and other precious metals.

- With the demise of apartheid, U.S.-South Africa trade and investment prospects have improved significantly.

- Until recently, foreign direct investment was severely constrained by opposition to apartheid. Foreign investors are now looking at South Africa once again. As of 1992, U.S. companies had $\$ 1$ billion in direct investments in South Africa.

- Abolition of the financial rand in March 1995 opened the door to free movement of capital by foreign investors into and out of South Africa, and demonstrates the government's commitment to economic reform.

U.S.-S.Âírican Trade Baiance* 1994-1995

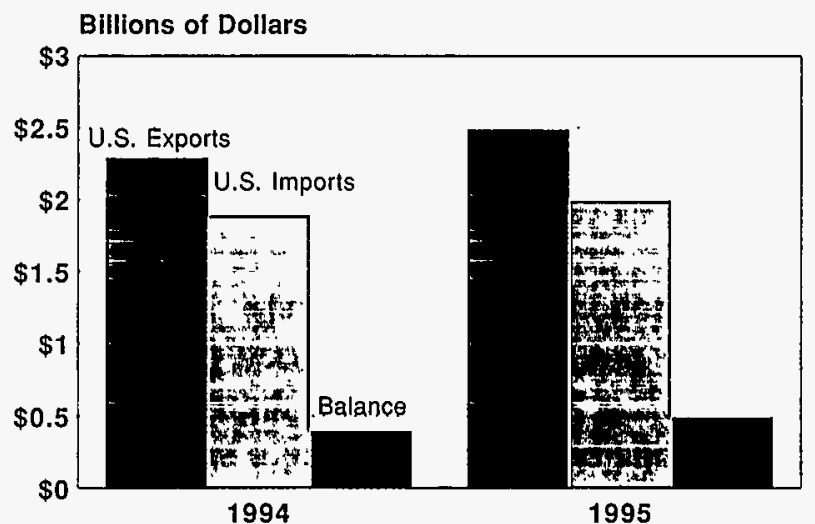

Source: The Economist Intelligence Unit - Morchandise trade

\section{U.S.-South Âírican Trade by Sector, 1995}

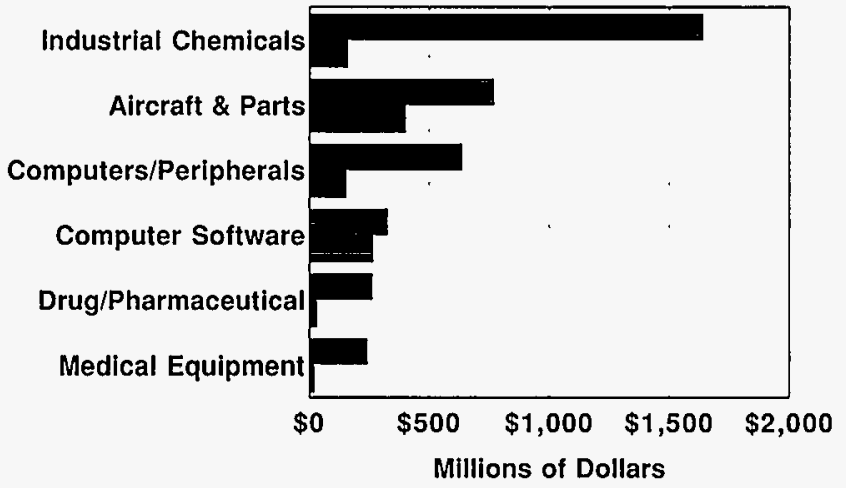

Total Imports $\square$ Imports from U.S.

Source: US Dept. of Commerce, International Trade Administration 


\section{Energy in South Africa's Economy ...}

\section{Energy Consumption* per Dollar of GDP}

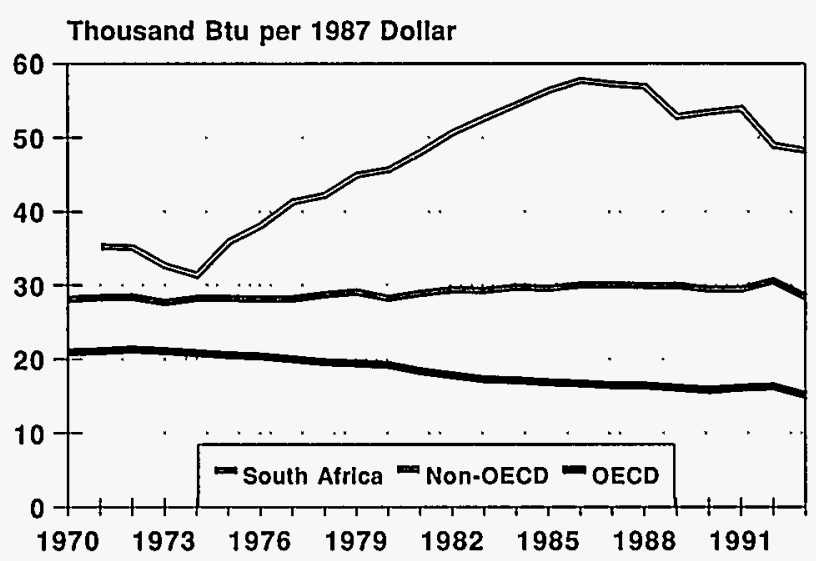

"Commercial energy only

\section{Energy Consumption* per Capita}

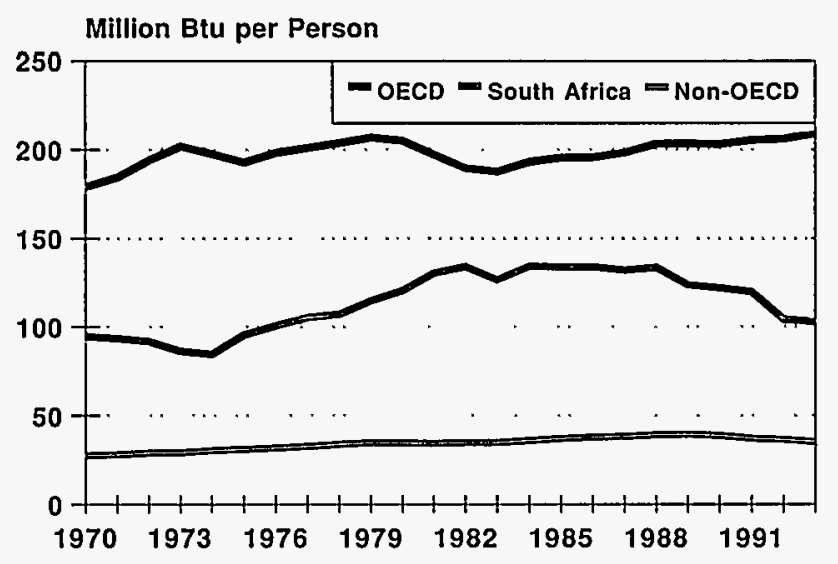

"Commerclal energy only

- South Africa's energy consumption per unit of output rose sharply between 1974 and 1986, but has fallen slightly since.

- South Africa consumes far more commercial energy per dollar of GDP than Organization for Economic Cooperation and Development (OECD) countries as a group, and also more than many non-OECD countries.

- South Africa's energy/GDP ratio increased by about $46 \%$ since the early 1970s, as energy consumption growth outpaced increases in economic output. Efficiency improvements over the next decade, however, could help to moderate growth in energy consumption relative to economic growth, although continued electrification likely will have the opposite impact.

- South Africa's per capita energy consumption is far less than the United States and Canada, but comparable to OECD countries like Italy and Japan and greater than most non-OECD countries.

- South Africa consumes only about one third the energy per person as in the United States. South Africa's per capita energy consumption has grown slightly, from about 93 million British thermal units (Btu) in 1970 to about 107 million Btu in 1995.

- Rural electrification should result in higher per capita commercial energy consumption in coming years. 
South Africa and the Environment ...

South Africa's Carbon Emissions* in a Non-OECD Context, 1970-2010

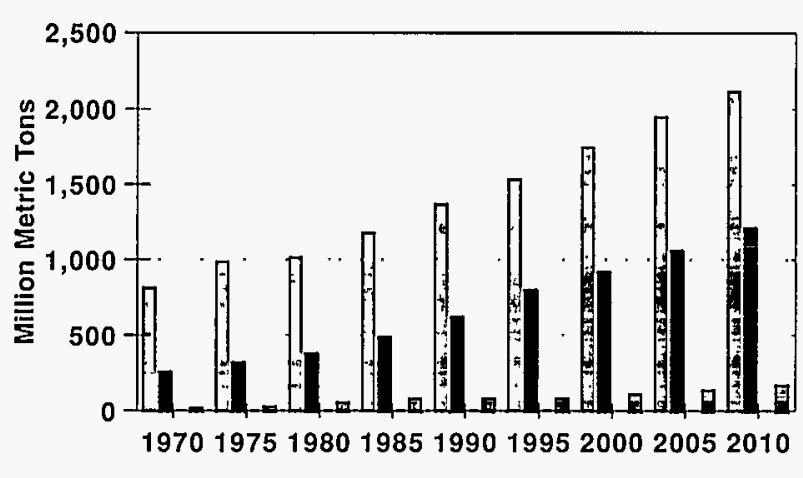

Dother Developing $\square$ China Former Soviet Union O South Africa

*Note: From commercial fossil fuel consumption only
South Africa's Carbon Emissions* in a Regional Context

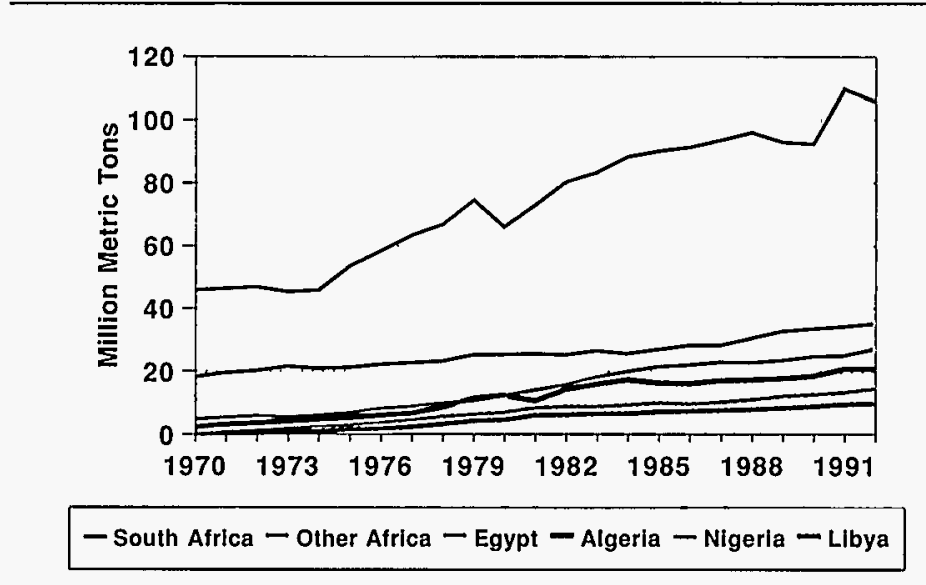

*Note: From commercial fossil fuel consumption only

- South Africa's main environmental issues include: carbon emissions, acid rain, and smog due largely to high coal consumption; shortages of clean water; and desertification aggravated by domestic fuelwood consumption.

- South Africa emits approximately 100 million metric tons of carbon from the consumption of fossil fuels, ranking 12 th in the world. South Africa's share of world energy-related carbon emissions is $0.4 \%$, ranking just behind Italy and France.

- South African coal tends to have a low sulphur content, so SOx emissions do not present a major problem for the country. Environmental problems related to coal mining, processing, and waste disposal are significant in the Transvaal region.

- Increased electrification could reduce air pollution from the burning of coal and fuelwood by many households in rural and poor "informal settlements" for cooking and heating. About one-third of South Africa's population still relies upon noncommercial fuels (mainly wood) for their everyday needs.

- The RDP, as one of its main goals, calls for creation of a "clean and healthy environment," particularly in the poorest areas of the country. How this will be achieved is an important, unresolved question facing the country. 


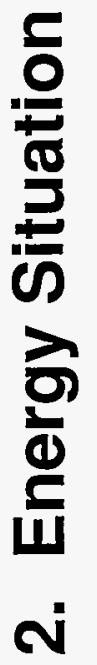




\section{South Africa Will Remain a Net Energy Exporter for the Foreseeable Future ...}

\section{South Africa's Energy Production and Consumption}

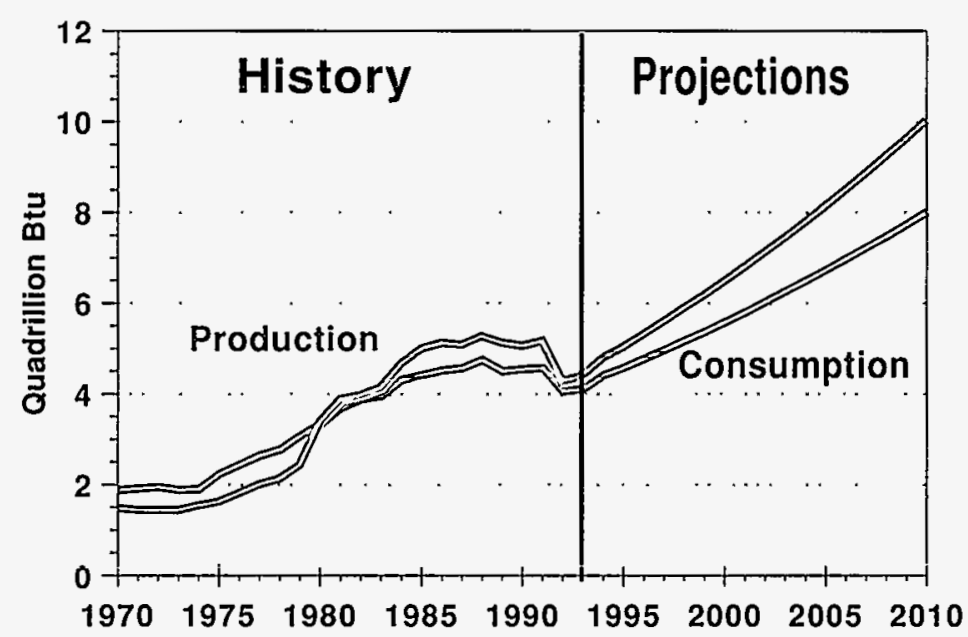

Note: All figures exclude renewable energy such as wood, biomass, solar, and wind. These sources constitute about a third of all energy used in South Africa.

- South Africa produces more energy than it consumes, and this trend is expected to continue through the forecast period. The country is a major coal exporter, and a net importer of petroleum. These trends are expected to continue through 2010.

- Between 1970 and 1991, commercial energy demand (i.e., not including wood, biomass, and other "traditional" fuels) in South Africa increased, on average, by 4.3 percent each year. Demand decreased by 11 percent in 1992 before increasing by 1.1 percent and 7.3 percent in 1993 and 1994 respectively. Between 1994 and 2010, South African energy demand likely will grow on average by about 3.8 percent per year, outpacing real GDP growth of 3.3 percent during that period. 
South Africa's Energy Production is Dominated by Coal ...

\section{Energy Production by Fuel Type, 1970-2010}

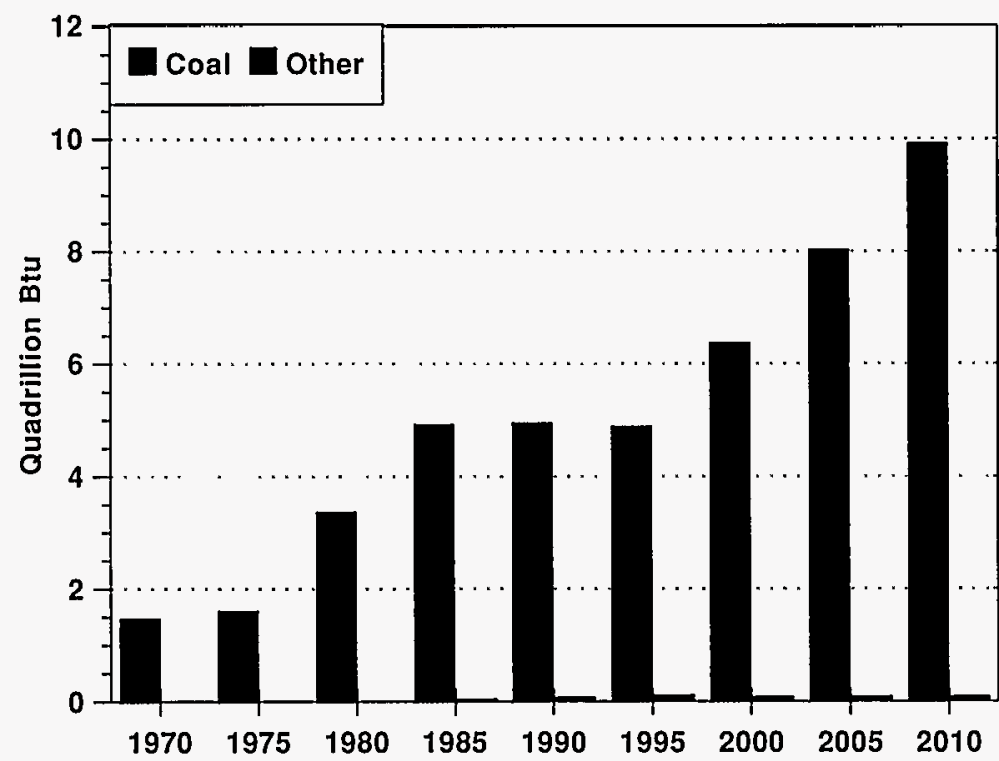

- In 1994, coal accounted for nearly 97 percent of South Africa's primary energy production (coal, oil, gas, nuclear, and hydroelectric). In the same year, nuclear production accounted for 1.6 percent, natural gas 1.0 percent, petroleum 0.4 percent, and hydroelectric power only 0.1 percent of total energy production.

- South Africa's electric generating capacity is primarily coal-burning (90 percent). Nuclear, natural gas, and hydroelectric power account for the remaining 10 percent.

- South Africa's fuel mix is not expected to change significantly between now and 2010 .

Note: Excludes non-commercial sources such as wood, biomass, solar, and wind. These sources constitute about a third of all energy used in South Africa.

- Overall, South Africa's commercial energy production is estimated at more than 5 quadrillion Btu (quads) in 1995, more than a threefold increase since 1975. By 2010, commercial energy production is expected to exceed 10 quads. (For comparison, the United States produced about 67 quads in 1994 and is expected to produce about 76 quads in 2010 .)

- South Africa also produces significant amounts of synthetic liquid products, mainly from coal. 


\section{Coal Accounted for 77 Percent of South Africa's 1993 Energy Consumption ...}

\section{Energy Consumption by Fuel}

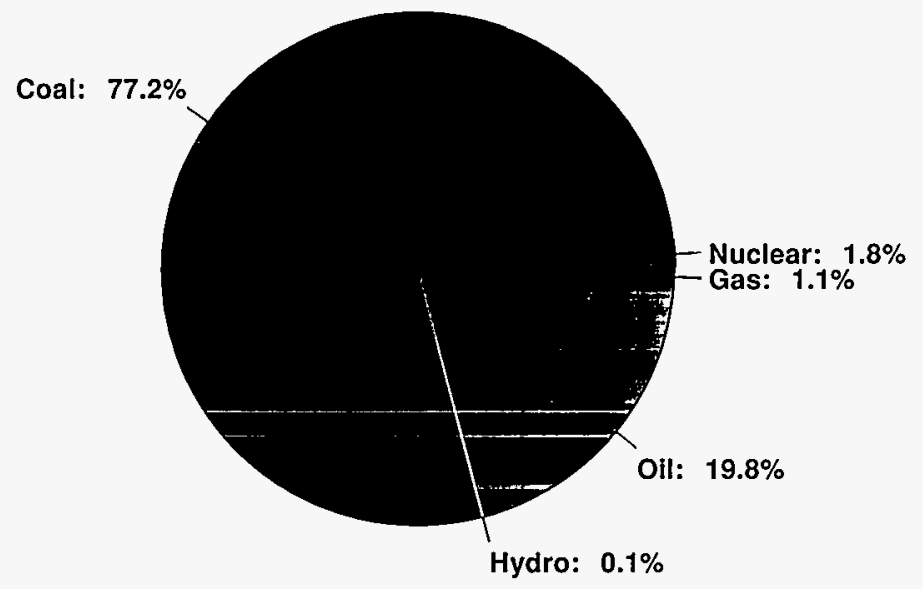

Total Consumption=4.15 Quadrillion Btu

\section{Energy Consumption by Sector}

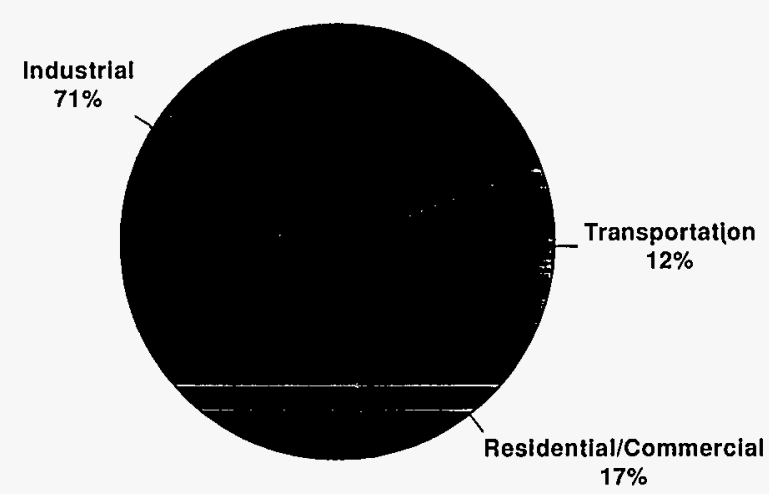

Total Consumption=4.58 Quadrillion Btu
"Electricity losses are distributed by sector.

Note: Graphs exclude non-commercial fuel sources such as wood, biomass, solar, and wind. These sources make up about a third of all energy used in South Africa.

- South Africa consumed 4.1 quadrillion Btu (quads) of commercial energy (not including "traditional" fuels) in 1993, representing about 1.2 percent of world commercial energy consumption. Of this amount, coal accounted for 3.2 quads (77 percent) and petroleum another 0.8 quads (20 percent).

- South Africa's industrial sector accounted for about 71 percent of South Africa's commercial energy consumption in 1990. The country's residential/commercial sector, in contrast, accounted for only about 17 percent of commercial energy consumption in that year, while transportation made up the remaining 12 percent. 
Over Three-Fourths of South Africa's Energy-Related Carbon Emissions Are Emitted by the Industrial Sector and Are a Result of South Africa's Reliance on Coal ...

\section{South Africa's Carbon Emissions* by Sector}

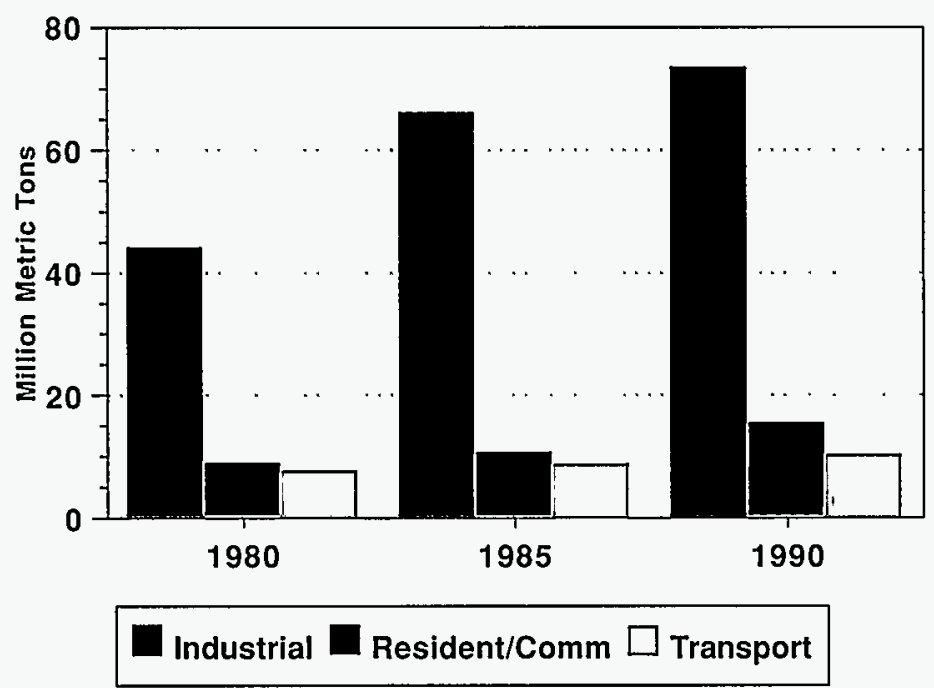

"From commercial fuel sources only

\section{South Africa's Carbon Emissions* by Fuel}

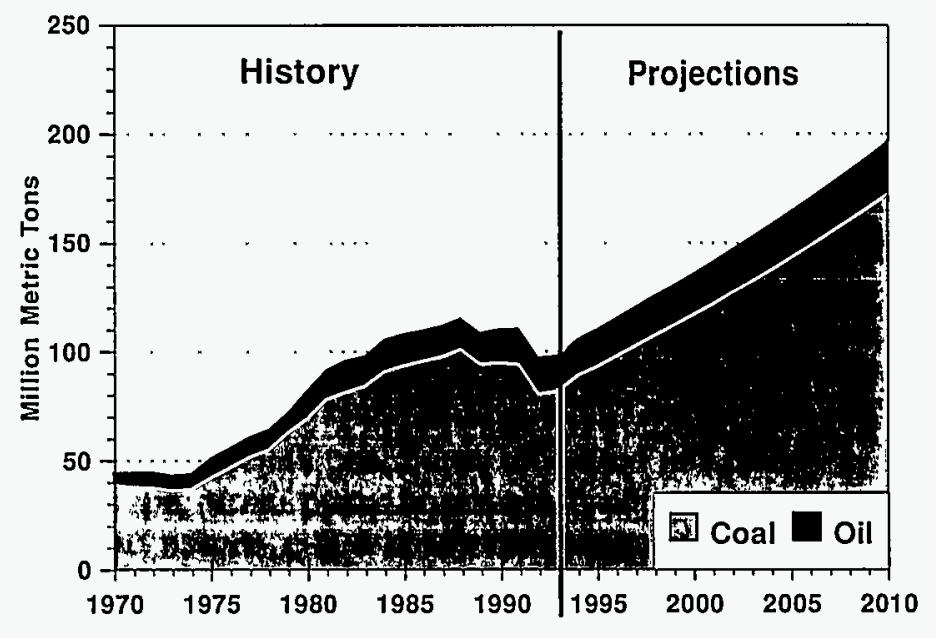

*From commercial fuel sources only

- South Africa's carbon emissions from coal, oil, and gas consumption grew $40 \%$ between 1980 and 1990 . In absolute terms, industrial sector carbon emissions grew the most (about 30 million metric tons) during the 1980s, while emissions in the transportation sector grew the least (less than 3 million metric tons).

- Coal consumption in South Africa accounted for 89 million metric tons of energy-related carbon emissions in 1994, or about 84 percent of the country's total commercial energy-related carbon emissions for that year.

- South Africa's carbon emissions from coal, oil and gas are expected to grow about 4 percent per year between 1994 and 2010 , compared to only 3 percent average annual growth in the 1980s. Increased consumption of coal due to a growing economy is the reason for this increased growth rate. 


\section{As the Demand for Energy Continues to Expand, the Challenge to Meet It Grows ...}

- Increases in South African commercial energy consumption in the near and mid-term will be driven heavily by three factors: 1) electrification; 2) economic growth and improved living standards among the majority black population; and 3) substitution of commercial fuels for traditional fuels.

- Increasing energy supply (overwhelmingly coal) will require major amounts of investment and technology, which at current international coal prices may not prove economical.

- An important question for South Africa is the extent to which energy activities will be run by the private sector. Another is the extent to which prices will be set by market forces.

- Energy-related environmental issues center mainly around coal: its mining, burning, and disposal of waste byproducts such as ash. Pollution is particularly concentrated in the Transvaal region, where most coal is produced, and in poor townships, where coal is burned directly for cooking and heating.

- Eskom, the country's major consumer of coal, has pledged to protect the environment by, among other things: 1) conserving energy; 2) reducing emissions, effluents and waste; 3) promoting renewables; and 4) improving energy efficiency.

\section{International Energy Agency (IEA) Outlook}

- Given the need for revenues to finance South Africa's RDP, energy taxes and subsidies undoubtedly will be subject to scrutiny, and likely will have an important impact on future South African energy trends.

- The key energy issue for South Africa is increasing the penetration of electricity into areas currently not served by the national grid.

- South Africa's industrial sector accounts for about 70 percent of total energy demand, compared to 17 percent for residential/commercial and 13 percent for transportation. Future transportation energy demand will depend mainly on increased incomes for the urban black population. Higher gasoline prices and a more fuel-efficient fleet could moderate this trend.

- Mining and manufacturing are major energy consumers in South Africa's industrial sector. South Africa's gold industry is extremely energy intensive. In 1991, for instance, 122 million tons of ore had to be extracted from deep mines to produce 601 tons of gold.

- South Africa's poor households rely heavily on traditional energy sources (mainly wood), along with direct burning of coal. This should decrease as electrification becomes more widespread.

Source: World Energy Outlook 1995 


\section{Energy Structure}




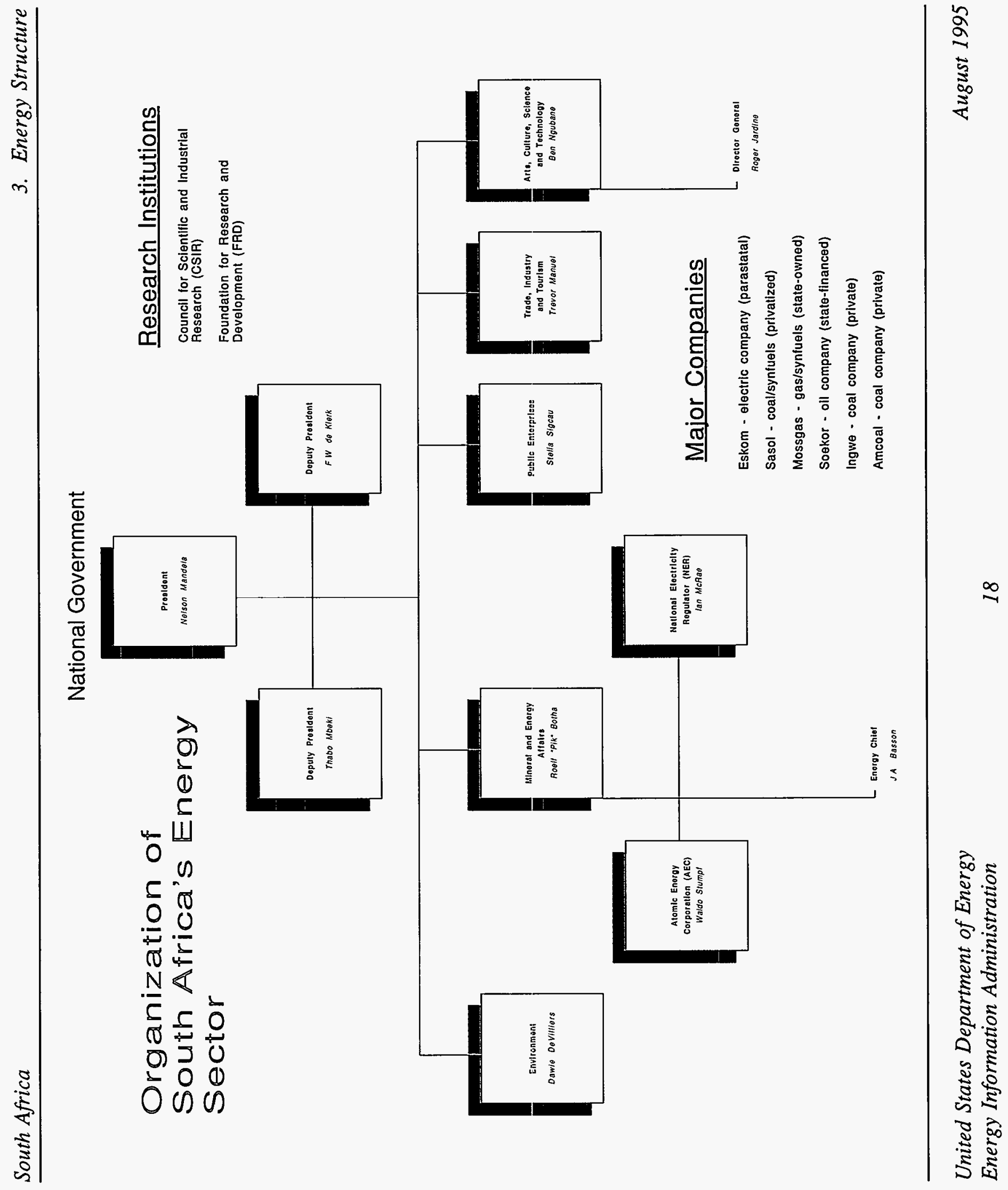




\section{The Key Decision-Makers Affecting South Africa's Energy Sector ...}

- President Nelson Mandela has two Deputy Presidents: Thabo Mbeki and F.W. de Klerk. Deputy President Mbeki co-chairs (with U.S. Vice President Al Gore) the U.S.-South Africa Binational Commission which includes an Energy Committee cochaired by South Africa's Minister of Mineral and Energy Affairs and the U.S. Secretary of Energy.

- The Ministry of Mineral and Energy Affairs is responsible at the national level for energy, minerals, and mining policy. Current Minister: Roelf "Pik" Botha

- The National Electricity Regulator (NER) licenses electric utilities. Current Chair: Ian McRae

- The Atomic Energy Corporation oversees the nuclear power program. Current Chief Executive Officer: Waldo Stumpf

- The Ministry of Public Enterprises has influence over electricity prices. Current Minister: Stella Sigcau

- The Department of Environmental Affairs and Tourism is responsible for global climate change issues as well as environmental management of toxic wastes and transboundary pollution issues. Current Minister: Dawie DeVilliers

- The quasi-governmental Council for Scientific and Industrial Research (CSIR) focusses its efforts on science and technology research and development, including electric power transmission, renewable energy, and clean coal.

- Eskom, South Africa's parastatal electric power company, receives no direct government funding; however, it receives loan guarantees and pays no federal taxes. Current Chair: John Maree Current Chief Executive Officer: Allen Morgan

- South Africa's coal companies are among the largest in the world. Major producers supplying coal to Eskom's power plants, industry, and the world market include Ingwe (created in late 1994 by the merger of Randcoal with Trans-Natal), Amcoal, Iscor, and Gold Fields.

- Sasol produces large quantities of coal for use in manufacturing synthetic fuels (synfuels), which it refines and sells in downstream markets. Mossgas produces and converts offshore natural gas to liquid fuels. South Africa has the world's largest synfuels industry. Current Director (Sasol): Jay Stegman

- Until recently, Soekor (Southern Oil Exploration Corporation), a state-financed "private" company created in the 1960's, had sole responsibility for oil exploration. The first award under an international licensing round held last October is expected by November 1995. Current Chief Executive: Joachim Heuser 


\section{Energy Is a Key Component of the Reconstruction and Development Program (RDP)...}
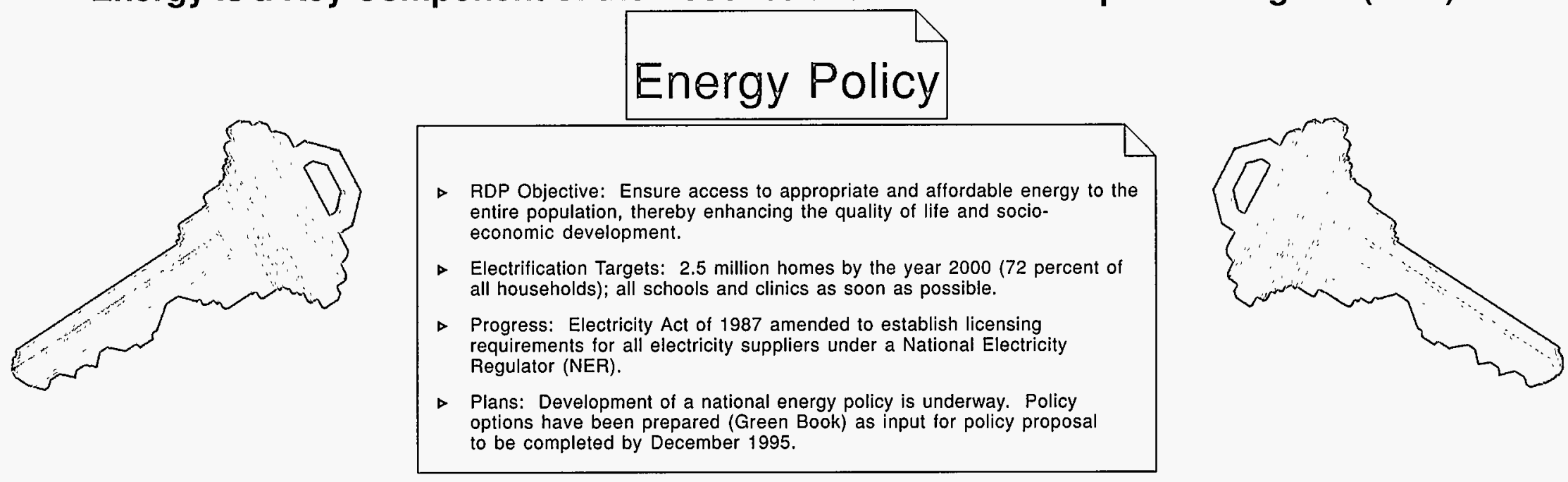

\section{Electricity Amendment Act, 1994}

$\checkmark$ Requires all suppliers of electricity to operate under authority of a license.

- Automatically provides a temporary license to all existing suppliers.

Changes the name of the Electricity Control Board (ECB) to National Electricity Regulator (NER).

$\checkmark$ Previously, departments of state, regional service councils, local government bodies, and Eskom were exempt from ECB regulation.

\section{National Electricity Regulator (NER)}

- NER's Objective: Ensure that the most effective electricity supply industry is put in place.

- Licensing: NER will license only those suppliers who can provide an excellent service at reasonable prices while meeting RDP electrification targets.

$\Delta$ Supplier Requirements: 1) technical/managerial capability to provide excellent service to customers; 2) financial resources to fund capital expansions and operate within national tariff parameters: 3) ability to electrify unelectrified areas within a reasonable period of time.

- Status: NER began operating in March 1995 and is reviewing applications for licenses received from Eskom and other utilities. NER plans to grant licenses in August 1995. 


\section{South African Electricity Grid}

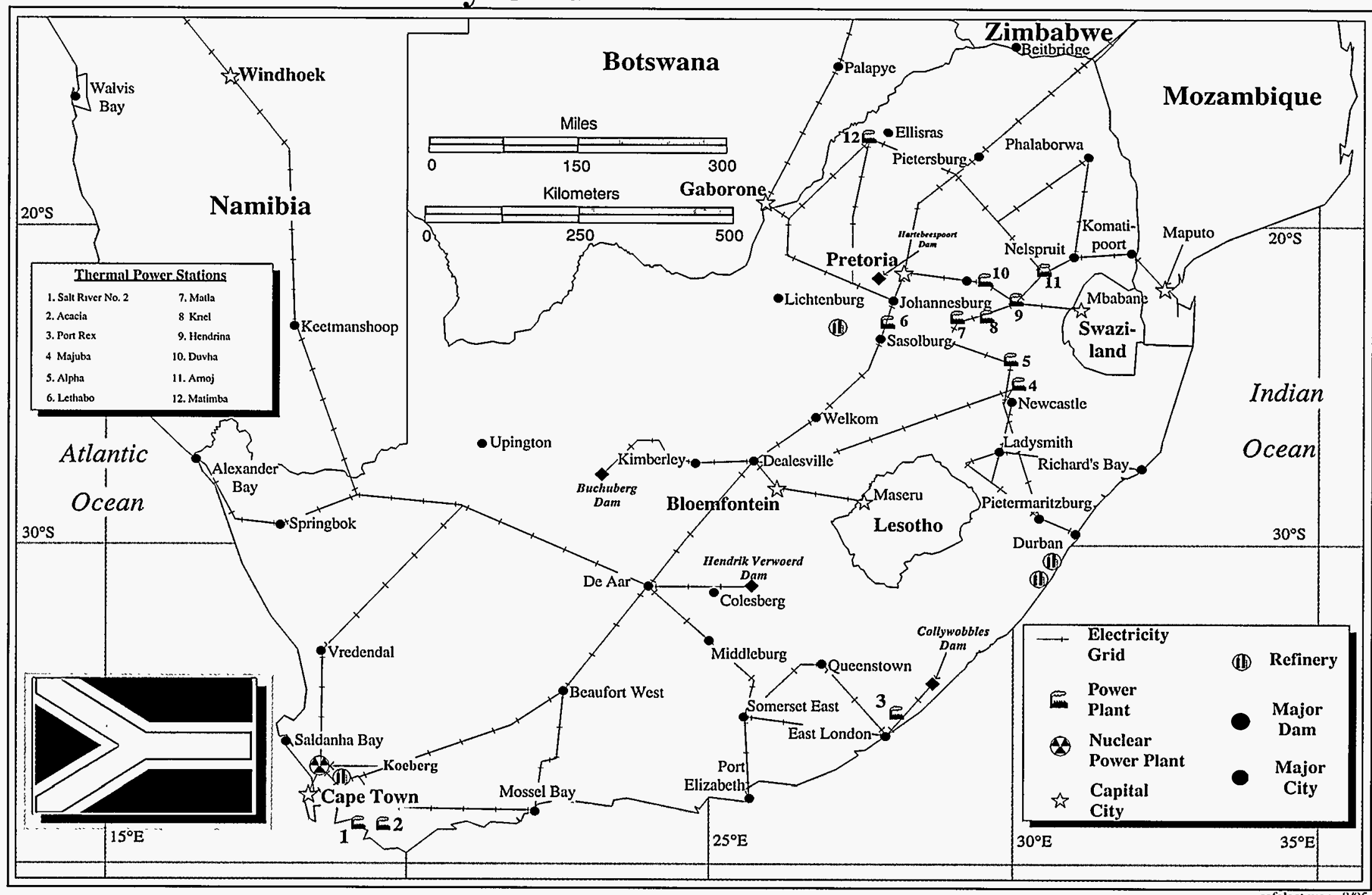

safelect.wor - $8 / 9$ 
A Quick Snapshot of

\section{South Africa's Electric Power Industry ...}

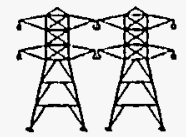

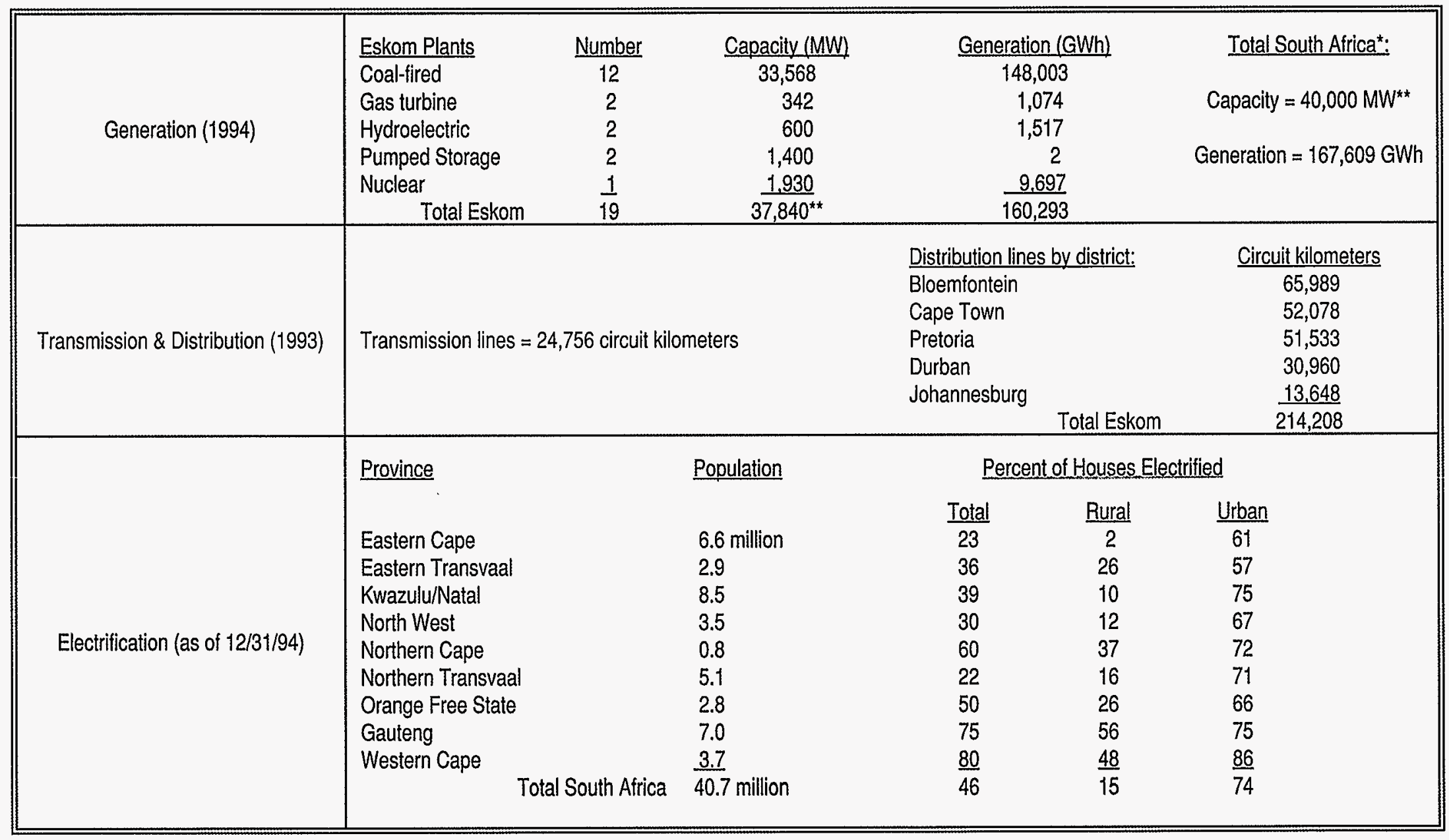




\section{Key Details About Electric Power in South Africa ...}

- South Africa has plenty of electric power generating capacity (40 gigawatts estimated in 1994), but lacks the necessary transmission and distribution systems to deliver power to more than half of the population. The main supplier, Eskom, is a parastatal company which is ranked the fourth largest utility in the world by capacity and the fifth largest by sales. Regional utilities supplement electricity produced by Eskom.

- South Africa produced 168,000 gigawatthours of electricity in 1994--more than half of all the electricity on the African continent.

- Nearly all of South Africa's electricity comes from coal-fired plants owned and operated by Eskom. Most coal power stations are located in Eastern Transvaal province, near the major coal-producing fields.

- South Africa's only nuclear power plant is Koeberg, located near Cape Town. The plant, built for strategic reasons, was commissioned in 1984. As an arid nation, South Africa has limited hydropower potential. Hydroelectric generating capacity consists of two dams on the Orange River. Gas turbines are used solely for occasional peaking requirements.

- Photovoltaics provide the major off-grid source of power (an estimated 3 megawatts). Other off-grid sources-in addition to petroleum-fueled generators used on a standby basis or in areas not connected to the grid--include some wind, biomass, and farm-based hydroelectric systems.

- Most of Eskom's main transmission system consists of 400-kilovolt $(\mathrm{kV})$ lines. Nearly three-quarters of its distribution lines are low voltage $(22 \mathrm{kV}$ and below).

- Electrification is a major element of the Reconstruction and Development Program (RDP). During 1994, Eskom reported the addition of more than 250,000 domestic connections. The nationwide goal is to add a total of 400,000 homes in 1995 and 450,000 homes per year thereafter (Eskom's share is 300,000 homes each year). By 2000, the government plans to have 72 percent of all homes electrified. The RDP also advocates affordable electricity prices. Under the RDP, Eskom is committed to reducing the price of electricity by 15 percent between 1995 and 2000 .

- Eskom exports electricity to Mozambique, Zimbabwe, Botswana, Namibia, Lesotho, and Swaziland. Sales to these countries totalled 2,628 gigawatthours in 1994. Future developments could include an integrated electricity grid linking all of sub-Saharan Africa. 


\section{South African Coal}

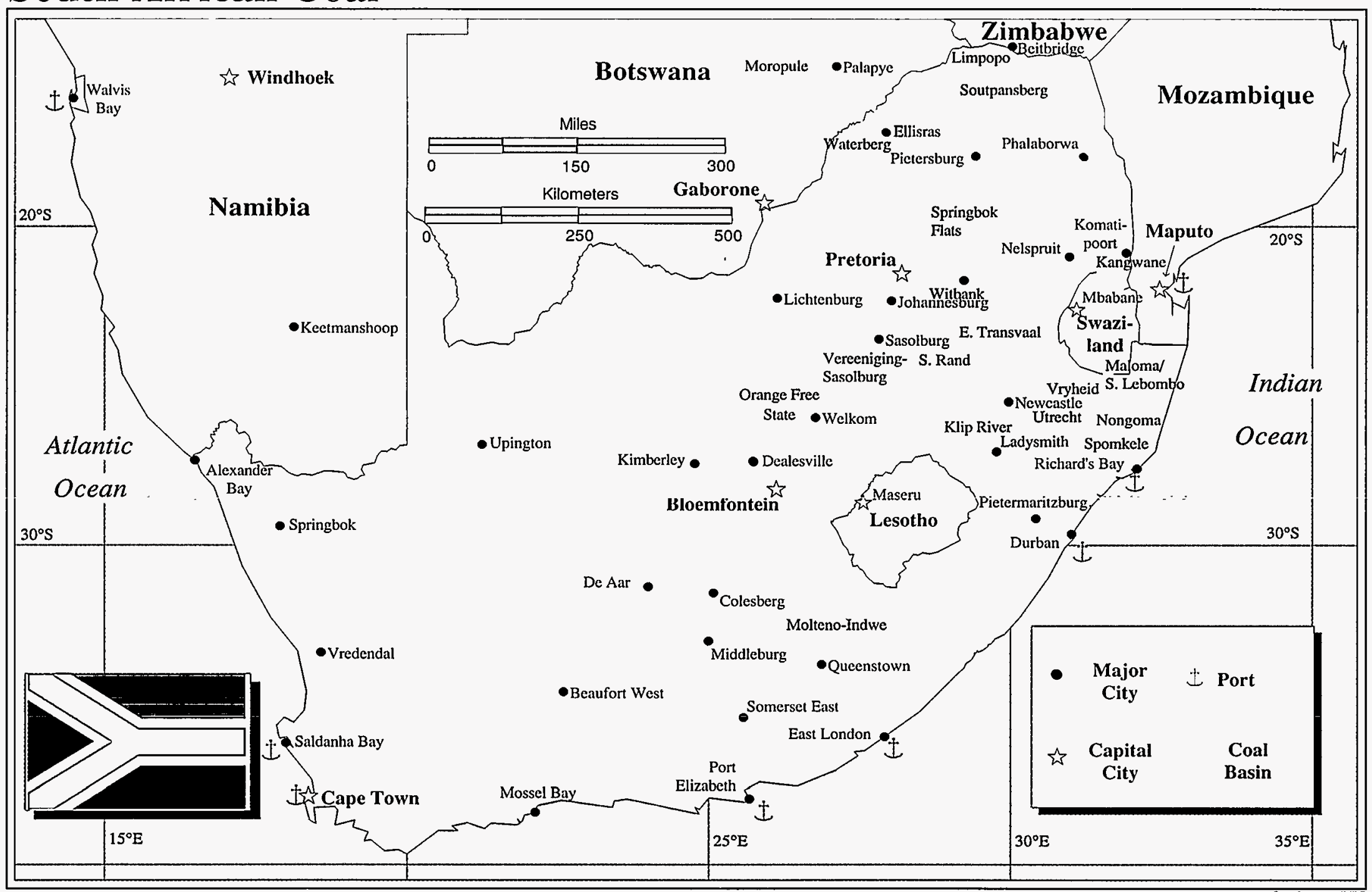

safcoal.wor - 8/95 


A Quick Snapshot of
South Africa's Coal Industry ...

\begin{tabular}{|c|c|c|c|c|}
\hline Reserves (1993) & $\begin{array}{l}\frac{\text { Province }}{\text { Transvaal }} \\
\text { Natal } \\
\text { Orange Free State } \\
\text { Cape }\end{array}$ & $\begin{array}{c}\text { Number of fields } \\
12 \\
4 \\
2 \\
\frac{1}{19} \\
\end{array}$ & $\begin{array}{c}\% \text { of Total Reserves } \\
85 \\
3 \\
12 \\
-- \\
100 \\
\end{array}$ & $\begin{array}{l}\text { Proven Reserves }(1993)=55 \text { billion metric tons } \\
\qquad \begin{array}{c}\text { (61 billion short tons) } \\
98 \% \text { bituminous } \\
2 \% \text { anthracite }\end{array}\end{array}$ \\
\hline Production (1993) & $\begin{array}{l}\text { Major Companies } \\
\text { Randcoal }^{*} \\
\text { Trans-Natal }^{\star} \\
\text { Amcoal } \\
\text { Sasol } \\
\text { Iscor } \\
\text { Gold Fields }\end{array}$ & $\begin{array}{c}\text { Million metric tons } \\
29.1 \\
21.1 \\
50.2 \\
41.6 \\
41.3 \\
10.6 \\
8.4 \\
\end{array}$ & $\begin{array}{c}\frac{\% \text { of Total }}{16} \\
\frac{12}{28} \\
23 \\
23 \\
6 \\
5 \\
\end{array}$ & $\begin{array}{l}\text { Total Production (1993) }=182 \text { million metric tons } \\
\text { (201 million short tons) } \\
179 \text { million metric tons steam } \\
3 \text { million metric tons anthracite }\end{array}$ \\
\hline Major Markets (1993) & Electricity production: $27 \%$ & Exports: $27 \%$ & Synfueis: $18 \%$ & Industry: $12 \%$ \\
\hline Exports (1993) & $\begin{array}{l}\text { Major Companies } \\
\text { Randcoal }^{*} \\
\text { Trans-Natal }^{*} \quad \text { Subtotal } \\
\text { Amcoal } \\
\text { Gold Fields }\end{array}$ & $\begin{array}{c}\text { Million metric tons } \\
11.2 \\
\frac{11.6}{22.8} \\
11.2 \\
1.1 \\
\text { Main Destinations: }\end{array}$ & $\begin{array}{l}\text { Percent of Total } \\
22 \\
\underline{23} \\
45 \\
22 \\
2 \\
\\
\text { wan, Spain, Germany, }\end{array}$ & $\begin{array}{l}\text { Total Exports }(1993)=51.2 \text { million metric tons } \\
\qquad(57 \text { million short tons }) \\
49.3 \text { million metric tons bituminous } \\
1.9 \text { million metric tons anthracite } \\
\text { ong Kong, Rotterdam }\end{array}$ \\
\hline
\end{tabular}

*Randcoal and Trans-Natal merged in September 1994 to form Ingwe, which is now South Africa's largest coal producer and exporter. 


\section{Key Details About Coal in South Africa ...}

- Coal is South Africa's most important energy resource. Proven reserves total 61 billion short tons (the seventh largest in the world), and annual production exceeds 200 million short tons. The reserves consist of bituminous (98\%) and anthracite $(2 \%)$.

- South Africa exports more than one-quarter of its annual coal production (57 million short tons in 1993), making it the world's third largest coal exporter after the United States and Australia. Its major customers are in the European Economic Community and the Far East. Coal is one of the country's top three foreign exchange earners; gold earns the most.

- South Africa's coal reserves are heavily concentrated in one region, northeastern Transvaal, which accounts for 90 percent of annual production. Reserves are primarily low-sulfur (1 percent) bituminous with a relatively high ash content (45 percent). Shallow depths and large seams make the coal relatively inexpensive to mine. Extraction costs traditionally have been among the lowest in the world, but have increased in recent years relative to competitors such as Indonesia and Australia.

- Ingwe, created in September 1994 from the merger of Trans-Natal and Randcoal, is South Africa's largest coal company. It is the world's largest steam coal exporter and third largest privately owned coal producer. The three largest companies (Ingwe plus Amcoal and Sasol) account for about three-quarters of annual production. Ingwe's predecessors (Randcoal and Trans-Natal) accounted for about $45 \%$ of 1993 export volumes.

- South Africa's coal companies operate 19 major fields, mostly located in the Transvaal and Natal regions. Development has been concentrated near Witbank (eastern Transvaal) where the coal is generally of better quality and less expensive to produce. The Natal area is noted for its reserves of anthracite.

- Richard's Bay Coal Terminal (RBCT) is the world's largest coal export facility, with a capacity of about 55 million tons per year. RBCT handles nearly all of South Africa's coal exports. Small amounts currently are exported out of Durban and the Mozambique port of Mabuto. RCBT currently operates near capacity. Potential expansion could boost export capability as high as 76 million tons annually by 2000 .

- Most of South Africa's coal consumption (144 million short tons in 1993) is used either for electric power generation or synfuel production. Prices were deregulated in 1988 and are significantly below the average price for Organization for Economic Cooperation and Development (OECD) countries. 


\section{Key Details About Oil and Gas in South Africa ...}

- South Africa does not have an abundance of oil and gas resources. Proven reserves are estimated to be $\mathbf{4 0}$ million barrels of oil and 959 billion cubic feet of natural gas.

- To compensate, South Africa invested heavily in advanced synthetic fuel (synfuel) technology to convert its abundant coal resources to liquid fuels. It now has the largest, most sophisticated synfuel industry in the world. The government subsidizes synfuel production as long as world oil prices remain below $\$ 21$ per barrel, but is considering phasing these out.

- Sasol's three plants in Secunda (in southeastern Transvaal province) liquify coal to a crude-oil equivalent (150,000 b/d capacity). Sasol supplies all of South Africa's petrochemical feedstocks and about a third of its motor fuels. Mossgas converts natural gas from an offshore field in Mossel Bay to gasoline and other light products (40,000 b/d capacity).

- In 1994 , synfuels accounted for $130,000 \mathrm{~b} / \mathrm{d}$ out of total South African oil production of $140,000 \mathrm{~b} / \mathrm{d}$. The Mossgas plant converted 46 billion cubic feet of natural gas to gasoline and other light products, at a rate of about 30,000 b/d.

- South Africa has four refineries with total capacity of $\mathbf{4 0 1 , 0 0 0 ~ b / d : ~ S h e l l / B P ~}(160,000 \mathrm{~b} / \mathrm{d})$ and Engen (65,000 b/d) in Durban, Caltex $(90,000$ b/d) in Cape Town, and Sasol/Total $(86,000$ b/d) in Sasolburg. Refiners recently completed a $\$ 700$ million upgrade/expansion for domestic and export markets, including preparations for the introduction of unleaded gasoline.

- Oil consumption totals about $\mathbf{4 0 0 , 0 0 0} \mathbf{b} / \mathrm{d}$, nearly all in the transportation sector.

- Oil imports (about 70\% from Iran) supplement synfuel production. Since 1991, South Africa has also been drawing down strategic stocks of crude oil (currently equivalent to 4-6 months of consumption) in part to raise revenue for social programs. In July 1995, the government agreed to store 15 million barrels of Iranian oil in two tanks at Saldanha Bay, near Cape Town.

- South Africa held its first open international oil and gas exploration licensing round in October 1994, covering 15 of its 19 offshore blocks. The first block is expected to be awarded in November 1995 . An earlier $\$ 800$ million investment by Soekor, involving the drilling of 230 wells, did not produce impressive results but indicated greater prospects for natural gas than oil.

- Except for the Mossgas project, South Africa has not invested in natural gas infrastructure. Historically, gas could not compete economically with cheap coal; however, environmental concerns could make gas more attractive. Future supplies are possible from natural gas fields being considered for development in neighboring Mozambique (Pande field) and Namibia (Kudu field). 



\section{Energy Investment Opportunities}




\section{Renewable Energy, Efficiency, and Environment}

\section{South Africa's Needs}

$\checkmark \quad$ About 60 percent of South Africa's households lack access to electricity, and many of these are in remote rural areas which cannot be reached economically by the national electricity grid. Such households are potentially more suited to off-grid, renewable-based systems.

$\checkmark$ Most unelectrified households currently rely on energy sources such as wood, coal, and kerosene. Almost 30 percent of the population still use candles as their main source of lighting, and almost 50 percent use wood or kerosene for heating. Non-commercial fuels such as wood account for more than one-third of South Africa's total energy consumption.

$\checkmark$ Noncommercial energy sources create serious environmental problems. Wond usage contributes to deforestation, while the burning of coal for cooking and heating creates localized airquality problems. Nationwide, household coal consumption contributes 20 percent of all particulate emissions even though it accounts for only about 3 percent of total coal consumption.

$\checkmark$ The Reconstruction and Development Program (RDP) promotes electrification, urban renewal (including housing construction), and sustainable development. To meet these goals, it needs to incorporate renewable energy systems (particularly in remote areas) and include energy efficiency features in construction projects.

\section{Market Opportunities}

$\checkmark$ South Africa's ambitious electrification program is creating opportunities for renewable energy, particularly in rural areas. The South African Financing and Implementation Agency for Renewable Energy (SAFIRE) will facilitate electrification in remote rural areas not economically reachable by Eskom. In addition, the Independent Development Trust will spend $\$ 15$ million by end-1996 to electrify rural clinics.

$\checkmark$ Photovoltaics (PV) could promote sustainable development goals by replacing wood as a source of household energy.

$\checkmark$ South Africa has abundant solar energy potential and a growing PV market. The country already has about 65,000 installed PV systems, totalling 3 megawatts. South Africa's Department of Mineral and Energy Affairs estimates that the market for PV systems will triple over the next several years, from 1.5 megawatts (mainly from U.S. factories) in 1994. Based on projected installations, 2 million homes, 9000 schools, and 2000 clinics will be using PV systems by 2015.

$\checkmark$ Currently, wind power is used mainly to pump water. Market potential for this application could reach 1.5 megawatts over the next several years. Future applications could include utility-scale wind power. Potential for such systems exists along the coast of the Eastern Cape.

$\checkmark$ South Africa is seeking cooperative manufacturing joint ventures which combine state-of-the-art PV, wind, and energy efficiency technologies with the country's large labor pool. 


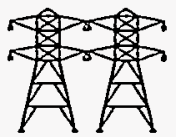

\section{South Africa's Needs}

$\checkmark$ Despite the fact that state-owned electric utility Eskom has over 10,000 megawatts of excess generating capacity, only 40 percent of South Africa's households are currently connected to the power grid.

$\checkmark \quad$ Electricity demand should grow rapidly along with economic growth of over $3 \%$ per year, and as new customers are added under the Reconstruction and Development Program (RDP).

$\checkmark$ Regional integration of South Africa with its Southern African neighbors has sparked interest in the establishment of a Southern Africa Power Pool, which already has been agreed to in principle at the utility level. The pool would center around coal-fired plants in South Africa and hydropower facilities in neighboring countries. By the end of 1995, the Botswana Power Corporation, Zimbabwe Electricity Supply Authority, Zambia Electricity Supply Corporation, and South Africa's Eskom are expected to be operating as a pool. The pool could eventually include all member countries of the Southern African Development Community as well as Zaire.

\section{Electric Power}

\section{Market Opportunities}

$\checkmark$ The RDP's goal is to increase electrification of households, schools, and clinics dramatically by 2000 . Eskom alone plans to electrify (through grid connection) 1.75 million homes by 2000. An additional 750,000 homes will gain access to electricity from other distributors and non-grid electrification projects in rural areas, bringing the total to 2.5 million newly electrified homes by 2000 (and $72 \%$ of all homes electrified).

$\checkmark$ Since Eskom already has surplus generating capacity, most of its investment will be in the area of transmission and distribution systems.

$\checkmark$ As the demand for electricity grows, so will the need for energy services, demand-side management, and integrated resource planning. This will create demand for labor skills which are currently in short supply in South Africa.

$\checkmark$ If the regional power pool develops as expected, large transmission systems will be needed in order to expand electricity trade within southern Africa. 


\section{Petroleum and Natural Gas}

\section{South Africa's Needs}

$\checkmark$ Most international oil companies pulled out of South Africa during the apartheid era, and exploration efforts by statefinanced oil exploration company Soekor during this time were generally not very successful. South Africa is now inviting foreign participation in oil and gas exploration.

$\checkmark$ South Africa is rethinking its commitment to the production of synthetic fuels (synfuels), particularly whether synfuels remain economically viable since the end of international sanctions.

$\checkmark$ South Africa needs to make greater use of relatively cleanerburning fuels such as natural gas in order to meet the RDP's sustainable development and environmental goals. However, South Africa currently lacks basic infrastructure needed to support a market for natural gas.

\section{Market Opportunities}

$\checkmark$ South Africa held its first open oil and gas exploration licensing round in October 1994. During this round, bids were invited on 15 of the country's 19 offshore blocks. The first award is expected in November 1995.

$\checkmark \quad$ The end of apartheid reduced the importance of energy selfsufficiency for South Africa. South Africa is now pursuing regional integration with its southern African neighbors, which could involve natural gas imports from either the Pande field in Mozambique or the Kudu field in Namibia. Development of these fields depends on the existence of a natural market and necessary infrastructure in South Africa.

$\checkmark \quad$ The key factor in whether South Africa will invest in building a natural gas infrastructure is the extent to which industrial firms commit to using natural gas. Anticipated environmental controls and regulatory structures could encourage industry to use natural gas.

$\checkmark$ South Africa is considering selling its Mossgas synfuels unit, which converts natural gas from the offshore Mossel Bay gas field to make gasoline and other light products.

$\checkmark$ South Africa's large coal reserves contain significant amounts of coalbed methane located in coal seams relatively close to established infrastructure and consuming areas. Sasol is looking into the possibility of using coalbed methane as a feedstock for production of synfuels. 


\section{Coal}

\section{South Africa's Needs}

$\checkmark$ Coal consumption in South Africa (currently almost $80 \%$ of total energy consumption) could more than double by 2010 , largely to meet electrification goals under the Reconstruction and Development Program (RDP).

$\checkmark \quad$ As part of its efforts at meeting the RDP's sustainable energy development goals, South Africa will need to expand the use of clean coal technologies.

$\checkmark \quad$ World marketing opportunities for South African coal are expanding. The key reasons are the lifting of international sanctions against South Africa and production difficulties encountered by competing coal exporters in Europe and the former Soviet Union. South African exports could increase to about 76 million tons by 2000 if: 1) new mines are opened; and 2) the capacities of coal export terminals are increased.

\section{Market Opportunities}

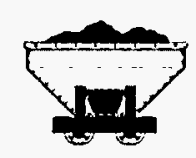

$\checkmark$ Increasing exports of South African coal will require the opening of new mines, mostly in the far-western Transvaal, and investment in transportation systems for coal shipment from new areas. Market opportunities exist for suppliers of mining equipment and technology to improve worker safety and productivity, which is necessary to remain competitive in world markets.

$\checkmark$ Increased coal exports would also require the expansion of the world's largest coal export facility, the Richard's Bay Coal Terminal, which currently has the capacity to handle 55 million short tons per year.

$\checkmark$ Environmental considerations are expected to become increasingly important as South Africa makes more use of its coal-fired power plants to meet increasing demand for electricity. As the export market expands, lower grades of coal are likely to be used domestically while higher grades are exported. As a world leader in clean coal technology, the United States has opportunities in coal preparation, fluidized bed combustion, integrated gasification combined cycle, and other technologies. 



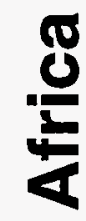

ભ

.

$\boldsymbol{\theta}$

E

0

ำ

III

0

0

8

(1)

E

6

E

E

두

6

(1)

D

1

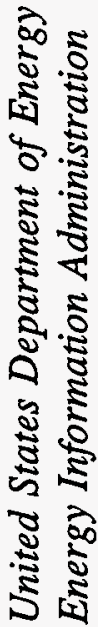




\section{Renewable Energy Activities in South Africa ...}

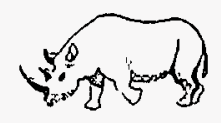

- Installation of photovoltaic (PV) systems

- With $\$ 30,000$ of seed money from DOE and co-funding from the South African Government and others, the Solar Electric Light Fund is installing a 200-watt photovoltaic (PV) system on a courthouse and 75-100 PV units rated at 50 watts on households in the village of Maphaphethe, outside Durban.

- The courthouse system will provide lighting for evening meetings and adult education courses; the household units will provide lighting and television.

- This effort will also test the viability of household financing systems for possible larger-scale projects in the future.

- Photovoltaic (PV) module manufacturing plant

- DOE is providing $\$ 624,000$ in a co-funded project with a South African business, Renaissance, and its subsidiary, Suncorp, to establish a PV module manufacturing plant produced by Spire Corp. (Bedford, MA) using U.S.-produced PV cells.

- This project builds domestic small, disadvantaged business capacity in South Africa, develops local technical capabilities, and increases the ability to meet the electricity needs of the dispersed populations with photovoltaics.

- Renewable Energy Training Center

- DOE, through Renewable Energy for African Development, is implementing a renewable energy training program for South African and U.S. Historically Black Colleges and Universities.

- The goal of the program is to build the necessary technical capacity for sustained renewable energy market development.

- The 5-year program consists of an annual training course (based in Africa) for African technical educators, curriculum development assistance, and the establishment of permanent regional renewable energy training centers throughout South Africa. 


\section{Fossil Energy Activities in South Africa ...}

- DOE is participating in several efforts with the private sector and utilities in the United States and South Africa.

- DOE is working with the U.S. private sector, Eskom, and the other state-run utilities of the Southern African Development Community (SADC) nations to address national and regional electrification needs and grid expansion.

- DOE is working with U.S. utilities and Artificial Intelligence (AI) systems suppliers to provide Eskom with commercial AI systems relating to utility boiler operating efficiency, pollution, and safety requirements.

- DOE has received several requests from South Africa for technical assistance.

- Eskom has asked for DOE assistance to determine the capability of U.S. Clean Coal Technologies, including fluidized-bed combustion, to address environmental cleanup of discard coal.

- SADELEC, a regional non-government organization concerned with electrification issues, has requested DOE funding support for the development of seminars in South Africa on energy utilization, pricing, and regulation as it relates to independent power production.

- The Council for Scientific and Industrial Research (CSIR) has requested DOE co-funding of a study on the efficiency and environmental impacts of coal utilization in utility/industrial boilers in South Africa.

- Sasol has requested DOE support to facilitate cooperation with U.S. firms to help adapt their technology to become more environmentally friendly. Sasol also has requested DOE support to determine applicability of U.S.- developed artificial intelligence (AI) technologies for process control and optimization of its coal conversion technologies.

- DOE also provides assistance to South Africa's government and industry through other venues such as meetings and conferences. Regional energy and environment opportunities were discussed at the Sub-Saharan Oil and Minerals Conference in Johannesburg (spring 1995). DOE is also sponsoring a Conference on U.S./African Energy Partnerships (to be held November 7-19, 1995 in Atlanta, Georgia). 


\section{Energy Efficiency Activities in South Africa ...}

- DOE's Office of Transportation Technology plans to fund a project, scheduled to begin in August 1995, to assess the needs of South Africa's transportation sector relating to electric vehicle technologies and the production of ethanol from biomass feedstocks.

- The project's goal is to develop partnerships between U.S. and South African companies for technology development arrangements relating to electric vehicles (EV) and the production of ethanol from biomass.

- This work is being funded through the Committee on Energy Efficiency, Commerce and Trade (COEECT)--an interagency group chaired by DOE--and the Export Council for Energy Efficiency.

- The project is planned to be conducted by the International Institute for Energy Conservation (IIEC) with support from its South African Partner, the Group for Environmental Monitoring (GEM) which is based in Johannesburg.

\section{Science Education and Technical Information Activities in South Africa ...}

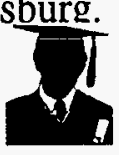

- Beginning in September 1995, DOE will implement a "training the trainers" project to assist South Africa's national campaign for scientific and technological education and training. The African Electrification Foundation, a U.S. firm, will provide contractual support.

- In the first phase of this project, selected students and professors at Black Colleges and Technikons in South Africa will receive scholarships to attend Historically Black Colleges and Universities in the United States for B.S. and M.S. engineering degrees. Supplemental training/presentations will be provided by selected DOE National Laboratories. This will include (contingent upon Fiscal Year 1996 funding) participation in existing programs such as the High School Honors Program and the Teacher Research Associates Program.

- The second phase will consist of a series of seminars for teachers in collaboration with South Africa's "I Can Training Foundation." Partners in this phase include the Historically Black Colleges and Universities, the National Laboratories, and private South African firms such as Eskom and Dimension Data. 


\section{Energy Information Activities in South Africa ...}

- The U.S. Energy Information Administration (EIA) and the South African Department of Mineral and Energy Affairs are working on setting up a formal agreement to exchange energy data and information, including formation of a sub-ministerial Working Group on Energy Information.

- These activities will include, but not be limited to: exchange of annual energy market statistics; exchange of other related energy data and information; sharing information on statistical methodology, analytic techniques, and system documentation; sharing information regarding electronic dissemination of energy information; and facilitation of electronic communication between the participants. 



\section{Appendix}




\section{International Aid to South Africa}

\begin{tabular}{|c|c|}
\hline Multilateral Development Banks & U.S. Assistance \\
\hline $\begin{array}{l}\text { World Bank } \\
\text { In April 1994, the World Bank opened a resident mission in South Africa at } \\
\text { the request of the country's transitional council. Activities focus on capacity } \\
\text { building and dialogue with intended beneficiaries of development. The World } \\
\text { Bank has participated in sector studies and provided technical assistance, but } \\
\text { has not made any loans to the new South African govemment. }\end{array}$ & $\begin{array}{l}\text { Agency for International Development (AID) } \\
\text { AID funding increased from } \$ 80 \text { million in fiscal year (FY) } 1993 \text { to } \$ 212 \text { million in FY } \\
1994 \text {. Financial aid for FY } 1995 \text { and FY } 1996 \text { is } \$ 166 \text { million in each year. } \\
\text { Program initiatives include Black Private Sector Development, Jobs, and } \\
\text { Infrastructure ( } \$ 268.6 \text { million for FY 1994-96); Strengthening Democratic and } \\
\text { Political Institutions ( } \$ 126.4 \text { million for FY 1994-96); and Education and Health } \\
\text { Delivery ( } \$ 133 \text { million for FY 1994-96). There is no direct funding of energy } \\
\text { projects. South Africa also receives some AID funding through the Initiative for } \\
\text { Southem Africa (ISA). The Southem Africa Enterprise Development Fund, which is } \\
\text { part of ISA, is investing } \$ 100 \text { million in small and medium-sized fims in the region-- } \\
\text { split equally between South Africa and its neighbors. }\end{array}$ \\
\hline 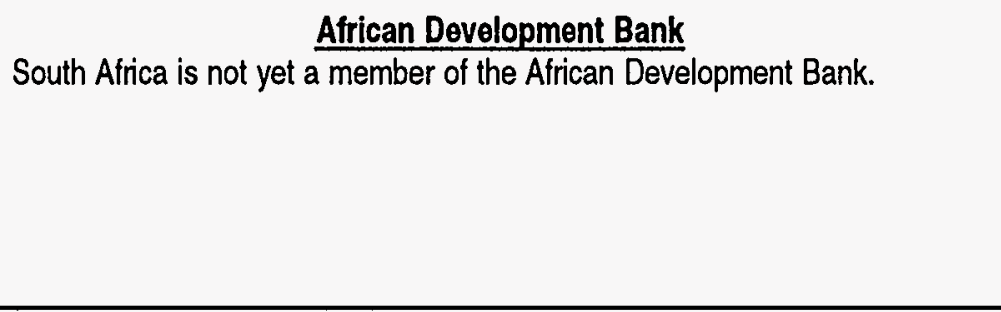 & $\begin{array}{l}\text { Overseas Private Investment Corporation (OPIC) } \\
\text { In April 1995, OPIC made its third investment mission to South Africa since the } \\
\text { United States nomalized commercial relations in } 1993 \text {. OPIC made one } \$ 9.3 \\
\text { million direct loan to a business in South Africa, and has insured } \$ 31.6 \text { million in } \\
\text { loans to two other firms. in addition, OPIC is launching the } \$ 75 \text { million Africa } \\
\text { Growth Fund II, an investment fund that will use private financing (guaranteed by } \\
\text { OPIC) to invest in sub-Saharan Africa. }\end{array}$ \\
\hline \multirow[t]{2}{*}{$\begin{array}{l}\text { European Investment Bank (EIB) } \\
\text { In October 1994, South Africa signed a bilateral agreement formalizing its } \\
\text { trade and development relationship with the European Union (EU). In March } \\
\text { 1995, the EU's European Investment Bank approved a loan guarantee of } 300 \\
\text { million European Currency Units, equivalent to about } \$ 400 \text { million. }\end{array}$} & $\begin{array}{l}\text { Trade and Development Administration (TDA) } \\
\text { TDA received authorization to open its South Africa program in April 1992. South } \\
\text { Africa's FY } 1994 \text { allocation was } \$ 1 \text { million (about } 20 \text { percent of TDA's } \$ 5 \text { million } \\
\text { budget for development projects in the Africa and Middle East Region). FY } 1995 \\
\text { funding for South Africa is also about } \$ 1 \text { million. }\end{array}$ \\
\hline & $\begin{array}{l}\text { Export-Import Bank (Ex-Im Bank) } \\
\text { In FY 1994, Ex-Im Bank financed } \$ 26 \text { million of exports to South Africa ( } \$ 5.3 \text { million } \\
\text { in direct loans and } \$ 20.7 \text { million in loan guarantees). Total Ex-Im Bank exposure in } \\
\text { South Africa as of October } 1994 \text { was } \$ 196 \text { million. }\end{array}$ \\
\hline
\end{tabular}


$\frac{2}{\frac{2}{10}}$

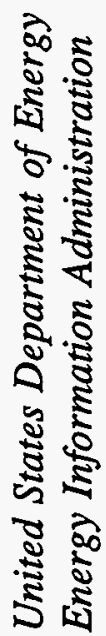




\section{Bibliography}

\section{South Africa Sources}

"A Glance at Electricity Distribution in South Africa," Eskom brochure, 1995.

"An Analysis of Liquid Fuels Consumption in South Africa," Department of Mineral and Energy Affairs.

Annual Report 1993, Department of Mineral and Energy Affairs.

Background on the South African Energy System, South African Energy Policy Research and Training Project, Energy for Development Research Centre, University of Cape Town, 1994.

CSIR Annual Report 1994 and CSIR Technology Impact 1994, CSIR, June 1994.

"Energy for Development in Southern Africa," Development Bank of Southern Africa and Department of Mineral and Energy Affairs.

"Energy in South Africa," Energy Research Institute, Cape Town.

"Energy Problems and Opportunities in Southern Africa," Energy Research Institute, University of Cape Town, September 1991.

Eskom Annual Report 1994 and Eskom Environmental Report 1994, Eskom, 1995.

Energy Use and Carbon Emissions: Non-OECD Countries, U.S. Energy Information Administration (EIA), December 1994.

International Energy Annual 1993, U.S. Energy Information Administration, May 1995.

International Energy Outlook 1994, U.S. Energy Information Administration, May 1995.
Eskom Statistical Yearbook 1993, Eskom, June 1994.

"Potential Energy Interchange in Sub-Equatorial Africa," Energy Research Institute, University of Cape Town.

Sasol Annual Report 1994.

South Africa: An Economic Profile, Standard Bank of South Africa, January 1993.

South Africa: The Journal of Trade, Industry, and Investment, February/March 1995.

South Africa's Mineral Industry 1993/94, Department of Mineral and Energy Affairs.

"Southern African Industrial Energy Demand - Scenarios and Strategy for Industrial Demand Management," Energy Research Institute, University of Cape Town and Department of Mineral and Energy Affairs.

Strategic View of the Energy Market, Eskom Marketing Intelligence, November 1994.

White Paper on Reconstruction and Development, Ministry in the Office of the President, November 15, 1994.

\section{U.S. Reports}

"South Africa - Oil, Gas Profile," U.S. Department of Commerce, International Trade Administration, May 1994.

World Fact Book 1994, U.S. Central Intelligence Agency, October 1994.

World Nuclear Outlook 1994, U.S. Energy Information Administration, December 1994. 


\section{International Organizations}

"Electrification: The South African Experience and Challenge," World Energy Council Journal, January 1995.

"Energy Supply for Development: The Southern African Case," Zambia Ministry of Energy and Water Development.

"Renewable Energy Opportunities in South Africa," U.S. Export Council for Renewable Energy (briefing paper), 1995.

\section{Journals and Forecasting Organizations}

"Africa Needs Rural Electrification to Ease Pollution", Bloomberg Oil Buyers Guide, November 7, 1994.

"African Energy Initiative: April 1994 meeting in Harare," Energy for Sustainable Development, July 1994.

"Coal: A South Africa Success Story," Mining Survey.

Country Profile: South Africa (1994-95), Country Report: South Africa (2nd Quarter 1995) and Country Risk Service: South Africa (1st Quarter 1995), Economist Intelligence Unit.

"Deregulation and Democracy Promise Energy Expansion," Petroleum Economist, April 1995.

"Mining Annual Review," The Mining Journal, July 1994.

"Petroleum Survey," supplement to the Financial Mail, December 3, 1993.

"Political Change Expected to Boost South African Coal", Journal of Commerce, June 30, 1994

\section{Electronic Sources}

Newsmanager for Windows, AP/Dow Jones Newswire service.

National Trade Data Bank, U.S. Department of Commerce.

LEXIS/NEXIS search of energy trade press and business news.

"South Africa: A New Perspective," Engineering and Mining Journal, September 1994.

"South Africa: A Review of Export Expansion," International Coal Report, April 3, 1995.

"South Africa: Oiling the Wheels of a Post Sanctions Economy," Weekly Petroleum Argus, November 7, 1994.

"South Africa Offers Exploratory Potential in Variety of Basins," Oil and Gas Journal, December 6, 1993.

"South African Coal," Mining Magazine, September 1994.

"Southern African Oil Ponders a New Era," Petroleum Intelligence Weekly, October 17, 1994

"Stronger South African Prices Leading to Financial Returns," Coal Week International, March 14, 1995. 